\title{
The educational needs of refugees in a multicultural world: An innovative solution to the problem
}

\author{
Kamil Arif Kırkıç ${ }^{* a}$, Ayşe Perihan Kırkıç ${ }^{* * b}$, Şeyma Berberoğlu ${ }^{* * * b}$ \\ ${ }^{a}$ İstanbul Sabahattin Zaim University, Faculty of Education, İstanbul/Turkey \\ ${ }^{\mathrm{b}}$ Istanbul Şehir University, Faculty of Education, İstanbul/Turkey
}

Article Info

DOI: $10.31704 /$ ijocis.2018.011

Article History:

Received 15 July2018

Revised 07 November 2018

Accepted 24 November 2018

Online 26 December 2018

\section{Keywords:}

Refugees,

Educational needs,

Multiculturalism.

Article Type:

Review

\section{Abstract}

In the last few decades, forced migration movements increased and caused a number of people to leave their countries and homes. In this context, especially existence and quality of food, health and educational services have great importance. Refugee children do not only need to have an access to humanitarian needs but also education. Even though it may be hard for the host countries to make a new system or have the refugees adapt to the established system, getting this responsibility is crucial in context of human rights. Education system of Turkey should be arranged according to the refugees and respect their identities. In this paper, a multicultural model proposal is presented to establish a better education life for Syrian refugees in Turkey.

\section{Çok kültürlü bir dünyada mültecilerin eğitim gereksinimleri: Soruna yenilikçi bir çözüm}

\section{Makale Bilgisi}

DOI: 10.31704/ijocis.2018.011

Makale Geçmişi:

Geliş $\quad 15$ Temmuz 2018

Düzeltme 07 Kasım 2018

Kabul 24 Kasım 2018

Çevrimiçi 26 Aralık 2018

\section{Anahtar Kelimeler:}

Mülteciler,

Eğitim intiyaçları,

Çok kültürlülük.

\section{Öz}

Geçtiğimiz yıllarda, zorunlu göç hareketleri artmış ve pek çok insanın ülkelerini, evlerini terk etmesine neden olmuştur. Bu bağlamda, göçmenlerin eğitim, beslenme ve sağlık intiyaçlarının giderilmesi ve niteliği büyük önem taşımaktadır. Göçmen çocukların, insani temel yardımların dışında eğitime de ihtiyaçları vardır. Göçmenleri barındıran ülkelerin, onlar için yeni bir eğitim sistemi tasarlayarak veya mevcut eğitim sistemlerini göçmenlerin ihtiyaçlarına uyarlayarak, göçmenlere eğitim hizmeti sağlamaları, insan hakları bakımından bu ülkelerin görevidir. Türkiye eğitim sistemi göçmenlerin kimliklerini de dikkate alarak onların ihtiyaçlarına göre düzenlenmelidir. Bu makalede Türkiye'de yaşayan Suriyeli çocukların eğitimi için bir model önerisi sunulacaktır.

\footnotetext{
** Author: arifkamildr@gmail.com

** Author: aysekirkic@std.sehir.edu.tr

*** Author: seymaberberoglu@std.sehir.edu.tr
}

Orcid ID: https://orcid.org/0000-0002-8902-437X

Orcid ID: https://orcid.org/0000-0001-6757-4795

Orcid ID: https://orcid.org/0000-0001-7451-642X 


\section{Introduction}

In last decade, mobilization increased especially due to increasing technology and welfare level and there are so many people on the move in different contexts. Migration movements caused people to move all around the world. Unfortunately, forced migration movements occurred because of war, famine and contagious diseases. Syrian War has had huge effects both inside and outside of the country. Syrian War, which started in 2011, caused 5.5 million people to migrate from Syria (UNHCR, 2016a). Turkey, Lebanon, Iraq, Iran, Jordan, Egypt and some European countries host these refugees. Turkey's geographical position makes it the leader country in context of hosting refugees. In addition to that, The Geneva Convention, which was signed by Turkey in 1951, accepts refugees those who only migrate from Europe and this situation still continues in that geographical limitation (United Nations High Commissioner for Refugees Representation in Turkey, 1961). This causes arguments about the naming of individuals from Syria who migrated to Turkey forcibly. In the first stage, refugees were called as "guests" but then they were registered as people who are in Temporary Protection. According to Republic of Turkey, Ministry of Interior Directorate General of Migration Management there are 3.594.232 people who are within scope of Contemporary Protection in 2018 (Turkish Ministry of Interior Directorate General of Migration Management, 2018). Increasing number of refugees has some significant effects on countries. It is of great importance for countries to recover and improve their systems in terms of infrastructure, education and health systems. Refugees' effects are not only limited to sharing resources. Demographic effects are also inevitable. Besides, different policies implemented by countries have an impact on refugees. It is critical to regulate the rights of refugees to live in humanitarian conditions in the country such as education, health and participation in the workforce. Especially when the young refugee population is considered, refugee youth should be well educated as well as every young person. These young refugees' effects on countries are the same with young citizens' effects. As a result, these young people should be well educated.

Considering the fact that $48.00 \%$ of the total of refugees are under the age of 18 , the applied education policies are important for the future of both Turkey and refugee children. Turkey's refugee education policy is highly critical for refugee children to sustain their lives and adaptation to society. Syrian refugees' mother tongue is Arabic, which is different from Turkish. As a result, these refugee children basically have a language barrier. To solve this problem, curriculum of schools should be revised. If these arrangements will not take place, not only Turkey but also other host countries will face with a wide range of problems like early child marriage, child labor and employment of refugees in illegal ways. Turkey has been taken highly important steps to decrease child marriage, but if it is not focused on refugee education, this problem may re-emerge in society. To avoid these problems, host countries should focus on education. Turkey provides free education for Syrian children but there is not any legal article, which states that refugees' education, is mandatory until university. For Turkish citizens, there is a system called $4+4+4$ and all Turkish citizens have to get education until university. From this perspective, Syrian students do not have the same opportunity as Turkish citizens. There are number of difficulties that Syrian refugees face, such as language barrier of both families and children, economic conditions, prejudices towards refugees. Unfortunately, due to these difficulties, 61 per cent of refugee children who are at school age cannot be enrolled to primary or secondary education in Turkey (UNHCR, 2016b). Syrian students are going to Temporary Training Centers. These centers are located in some government schools. Refugee children get education after Turkish children's classes finish. In these centers, Syrian curriculum is covered and given by Syrian teachers. In addition, Turkish teachers give Turkish classes. By 2017-2018 academic year, Syrian students are supposed to integrate into Turkish government schools with Turkish students. However, Turkish education system is not based on integration and identity based curriculum has been taught in Turkish governmental schools. There is no also class or curriculum that emphasizes the importance of multiculturalism. There is no class that Syrian children will understand the Turkish culture or vice versa. Due to lack of multiculturalization and adaptation, prejudices against refugees have started to occur as acts of hate crime both in Turkey and around the world ("Altın için Komşularını Öldüren Suriyeliler Tutuklandı", 2018). To eliminate prejudices, the education system should be based on multiculturalism and global values should be told to students. In addition, hate speech against refugees has increased all around the world. Some examples about hate speech in Turkey can be seen in real life and social media unfortunately. To have a peaceful society, youth that are more conscious should be raised in a multicultural form. In this paper, initially the situation of refugees around the world is discussed and then specifically, some solution proposals to the educational lives of refugees are presented. 


\section{An "Issue" of the Contemporary World: Refugees}

As Ormsby stated, since 2011, the number of displaced people around the world has increased more than 50 per cent (2017). Year 011 was so critical because Syrian War started and affected 5.5 million people, caused them to become refugees (UNHCR, 2016a). Forced migration caused them to leave their country like Afghans and South Sudanese people. "Forced migration is not something we discover but something we make" (Working, No \& Turton, 2003, p. 3-17). Political and economic problems not only do affect refugees' lives but also all the world. Displacement can cause so many problems in host countries. In addition, refugees' traumas, identity fights and struggle for life is so depressing (Silove et al., 1997). One of the most significant effects of forced migration is that it affects all people from all socioeconomic backgrounds. A person can be a millionaire, an intellectual or a worker but all of them can be affected by migration at the same time. Also, it may be nonvisible for so many people but children are affected from forced migration issue so much. They may have trauma, chronic diseases during the migration process and afterwards (Gans, 2009). Life standards of immigrants decreases steadily after migration. However, to survive in these standards refugees need support from local authorities, NGO's (Non-Governmental Organizations) and societies. One of the ways to increase refugees' life standards is education. Giving them an appropriate education and creating a common culture would affect their lives profoundly.

Adapting to a new culture is hard for refugees because they migrate into societies that have a very different structure from theirs. As an example, 90 per cent of top 10 countries, which accept high number of refugees, are developing countries. To stay in camps in a developing or developed country is perceived irrational by refugees. They seek job opportunities in these countries rather than staying in a shelter. UNHCR states that in Turkey, 91 per cent of refugees are living in cities (2017b). Turkish government gives work permits to refugees. Okyay states that, at the end of 2016, 13,298 Syrian refugees had work permits (2017). Considering the adult number of refugees in Turkey, this number is low. Some of these refugees are entrepreneurs who have opened their own restaurants or companies but still there are so many blue-collar workers. But unfortunately, a high number of illegal labor exists, too. Business owners view migrants as cheap labor and employ them illegally (Erdoğan, 2018). Especially due to hard economic conditions in big cities, high house rents and high prices lead children to become worker. Though this is illegal, refugee children are forced to work. The United States Department of Labor also states that in textile, furniture and manufacturing sectors child labor has been increasing, and these children get less than half of the wages that are given to adults.

Pakistan is the second country that hosts the highest number of refugees. Most of the refugees in Pakistan have come from Afghanistan. Around 1.4 million refugees are living in Afghanistan. Afghan refugees also live in some European countries and Iran. Most of the Afghan refugees are living in Iran and Pakistan, which are developing countries. Also in 2016, in Iraq 953.447 and in Turkey 118.116 Afghan refugees are living (UNHCR, 2016a). Developed countries have fewer Afghan refugees compared to developing countries (Human Rights Watch, 2017). Due to political issues between Afghanistan and Pakistan, as a host country Pakistan has been implementing refoulement to these refugees. UNHCR numbers showed that in 2016, 1.737 .882 refugees came back to Afghanistan though they had lack of humanitarian resource and job opportunities (2017b). In Afghan refugees' case, the number of children refugees are high, too. More than half of the Afghan refugee population is children (UNHCR, 2017b). Moreover, 74 percent of Afghan refugees living in Pakistan are below the age of 24 (UNHCR, 2016a). Giving education for these children is crucial because there is a non-negligible existence of terror in that geography. Education has a huge place to keep these children safe and add value to their lives.

Lebanon is the third country that hosts highest number of refugees. Lebanon hosts 1 million Syrian refugees (UNHCR, 2016a). Lebanon has some advantages concerning refugees due to its geographical proximity. The language of Lebanon is the same as Syria, Arabic. In addition, cultural differences are possibly fewer than Turkey or any other country that Syrian refugees are living in. However, Jesri states that there are not any formal camps spread around Lebanon (2015). This situation may affect the access to education in a negative way because if the government cannot gather refugees, it is hard to follow their needs.

Iran is the fourth country that hosts the highest number of refugees. Not only does Iran host Afghan refugees but it also hosts Syrian refugees. There are 979.435 refugees in Iran (UNHCR, 2016a). Afghan refugees can attend schools like the citizen of Iran. In Iran, refugee children are getting education based on country's curriculum (UNHCR, 2016b). This situation is critical because this curriculum is not multicultural and does not fit to refugees' culture.

In addition to the Iran and Lebanon, so many people have become refugees due to conflicts in South Sudan. Almost one third of the population of South Sudan is displaced. "More than 1.7 million South Sudanese have fled the country and an estimated 7.5 million people are in need of urgent humanitarian assistance inside 
South Sudan, including more than 1.9 million internally displaced people (IDPs)" (UNHCR,2017a). Sudanese people mostly migrate to neighborhood countries and all these countries are not developed countries like Sudan or developing countries. IRRA (International Refugee Rights Association) states that in Uganda there are 1 million South Sudanese refugees (2017). Due to economic conditions of host countries, refugee education is not so successful. UNHCR states that almost 65 per cent of these children cannot have access to education (2016a).

From all these examples, it can be clearly seen that migration movements affect children so deeply. These refugee children are getting education in cultures that they weren't born into. Moreover, some refugee children were born into a society that is very different from their families. For instance, according to AFAD (Disaster and Emergency Management), until July 2017, 224.750 children were born in Turkey (2017). As time passes, these refugee children will grow up in a multicultural world. Possibly, they will be bilingual, learn their mother tongue in home and learn the host country's official language in schools or during social activities. These refugee children will possibly have conflict with their identity in their minds. If the education system is redesigned based on refugee identity, global values and cultural combination, refugee children can be saved and reintroduced to society.

All in all, more than half of the refugees around the world are children (UNHCR, 2016a) and these children need to get proper education like normal citizen children do. Countries' approach toward them maybe different but they should meet certain needs of refugee children to a certain extent because these children are not bounded with national borders but they are the world's children. To save children, education is an important mechanism. In the next part of this paper, multicultural socialization and refugees' identity are discussed. After that, a curriculum proposal for refugee children in Turkey is given presented.

\section{Education, Multicultural Socialization and Reconstruction of the Identity}

Different countries and different people have different cultures. Globalization is a value that creates a new culture that everyone can meet in a common point. A Turkish person can wear blue jeans and a Japanese can wear blue jeans too. The spread of internet and social media also play a significant role here. These channels showed people that culture is not only restricted with the borders of countries. From these examples, it can be easily said that people from different backgrounds, cultures and countries establish a new culture that is called global culture. Multicultural socialization is another part of global culture. Multicultural socialization process is a significant way of having values, behaviors and cognitions from a different culture via social mechanisms. Education is one of the most effective social mechanism that combines cultures, discover talents and shapes identities.

Education encourages the improvement of human abilities and possibilities. With a specific end goal to locate the self and to investigate the potential that the individual has, the individual need to teach her psyche and soul. The individual distinguishes herself in light of the education that he/she has. Education begins in the family and proceeds through all lifetime. The education that is gotten from the family is the essential determinant of the personality development. Data that is found out from guardians that children have, the condition that children grow up, the racial or religious gathering that children have a place or companions that children play with are operators for the character development.

Vincent (2003) says that education is not only a question of the activity of the political rights but it is the way to the verbalization or generation of the character. In a few nations, education is an unquestionable requirement; however, in some others like African nations it is an extravagance. Despite the fact that education is a required commitment by the law, it assumes a key part on the development of the personality. Because of the cultural assimilation, refugees sometimes attempt to restructure their personality when they are in contact with another culture. Displaced individuals are uncovered refugees and therefore, they feel a need for reassemble and they reproduce their personality in like manner.

An administration approach, which looks out to end the clash between the two societies for the benefits of both parties, should give more social roles and responsibilities to immigrants in order to integrate them with the locals. So displaced people can build their character as indicated by the social part that they play in the public. In any case, it is precise for displaced people to adjust in a new society and culture. Regardless of the fact that they fled from the war, individuals had their own particular societies in their recollections and comprehensions. They should not to be torn from this culture since recollections that they have are vital and are essential for the development of the character. 


\section{The Place of Bilingualism in Refugees' Education}

Dewey \& Dewey state that education is a process of living not just a preparation for future life and education adds value to people not only in academic ways but also in social ways (2008). The combination of learning, values, cultures, and behaviors is also part of education. Nowadays, the aim of education has changed sharply. Value creation part of education has decreased because education has been served as a mechanical system. Meyer states that in today's world, education does not look like a process but it is more like a product (as cited in Bauman, 2003). Curricula are not based on improving creativity and exploring talents. All children sit the same exams even though their talents, cognitions are different.

Unfortunately, people see education as a bridge only to enter workforce system. Education's role on combining cultures, has been undervalued and focus has been mostly being part of workforce. To solve this issue, multiculturalism should be brought forward in education system and curricula. "Multicultural education is also a reform movement that is trying to change schools and other educational institutions so that students from all social-classes, gender, racial, language and cultural groups will have equal opportunity to learn" (Banks \& McGee Banks, 2010, p. 4-481). Language classes are crucial in multicultural education. Especially in the education of refugees, bilingualism is of great importance because growing up in a society where the mother tongue is not spoken can go as far as to distance the main cultures of refugee children and even to forget their mother tongue over time. The advancement of bilingualism with sound educational foundations is important for establishing a healthy bridge between different cultures.

Bilingualism is using two languages fluently. "The concept of bilingualism refers to the state of a linguistic community in which two languages are in contact with the result that two codes can be used in the same interaction" (Hamers \& Blanc, 2000, p. 6-49). Bilingualism is a way of cultural interactions between people. A country that has a huge culture mosaic, like Turkey, bilingualism is a way to connect cultures. Families, traditions and schools serve as a bridge on bilingualism. As stated above, there are 22.5 million refugees around the world. Communication among host countries' citizens and refugees is important. Bilingualism of refugees also supports multicultural connections. Multiculturalism is not restricted with one culture's adaptation to another culture. When each culture learns language, values and traditions of each other, embraces them, and uses them in their daily lives, multicultural socialization occurs. In a research conducted by Sunny Man Chu Lau, students from Canada and Burma became pen pals. Students from Burma were mostly refugees and Burmese students wrote some parts of letters in Burmese language while Canadians wrote in English to increase bilingualism practices. At the end of this research, students' perspectives about using different language were more positive and lost their fear of learning different cultures (Sunny, 2017). Bilingualism in multicultural societies should not be restricted with one cultural or ethnic group. Bilingualism of refugees cannot be the only source of multiculturalism because people living in a host country should develop bilingual skills; this type of interconnection will be more helpful for both sides.

The place bilingualism in refugee education is critical because by learning a new language, refugee children's identity can be shaped. As Blau and Duncan stated, "The most important means for immigrant groups and other ethnic minority groups to be absorbed into the mainstream culture may be education" (as quoted by Bankston \& Zhou, 1995, p. 3-17). Multicultural education does not aim absorption but adaptation. Thus, combination of multicultural education with bilingualism aims at increasing the adaptation process not absorption. In past, some absorption examples can be seen in different countries. The Congress of United States of America, made a legislation in 1906 that states, that if a person cannot speak English, she or he cannot have a right to be a citizen (as quoted by Bankston \& Zhou, 1995). These restrictions in countries, limits multicultural environment. Researchers conducted based on bilingualism showed that bilingual children keep their bonds with their native culture and show adaptation to other culture so bilingualism has favorable effects on children culture (Bankston \& Zhou, 1995). Memories of children in their native culture keep alive with bilingualism. "In such a world, memory was an asset and the further back it reached and the longer it lasted the more valuable it was" (Bauman, 2003, p. 21). When host countries are aware of the fact that memory is a huge asset for refugee children and shape education system based on multicultural values, refugee children can have a better future.

To conclude, multiculturalism shows itself hugely in bilingual education. Considering the fact that there are 22.5 million refugees around the world and almost 3 million of them are living in Turkey, a new curriculum for Turkish education system based on multicultural values can be crucial. To break prejudices for each other, to understand cultures better and to have a healthy cultural mosaic in society, reforms are needed in Turkish education system. In the next parts, refugee education in Turkey is analyzed and a curriculum proposal for Turkey is given. 


\section{Refugees' Education in Turkey}

Syrian War have affected a number of refugees in Turkey considerably. More than half of the refugees are children. Unfortunately, only 39 per cent of Syrian refugee children can have a chance to continue their education life in Turkey (UNHCR, 2016b). Children cannot go to school due to economic problems, psychologic problems, traumatic backgrounds or language barrier. Turkish government gives temporary settlement document to Syrian refugees and with this document, every child can attend government schools without paying any money. In some Turkish schools, Turkish government opened a center called Temporary Education Centre. Because of the location and establishment missions of these centers refugee children start education after Turkish children finish school. In these Temporary Education Centers, Syrian curriculum has been delivered and children learn Turkish in addition to that curriculum. By 2017-2018 fall semester, refugee children can start Turkish schools and most of the Temporary Education Centers have been closed all around Turkey to adapt refugee students into Turkish schools (Personal Communication with Ministry of Education of Eyüp District).

Unexpected rates of migration from Syria not only surprised Turkey but also surprised other countries. After migration, Turkish government started to find solutions for refugee education. Transitory Education Centers are one example of it. Still, some refugee children are going to schools that are not legal. UNICEF give monetary support to Transitory Education Centers. UNICEF pays teacher's salary and refugee children's monthly transportation payments in some Transitory Education Centers (UNICEF, 2015). Turkish Ministry of National Education states that, most of these Transitory Education Centers would be closed in 2017-2018 Fall semester and Syrian students would start regular Turkish schools and only minority of these Transitory Education Centers will continue (Ministry of National Education [Milli Eğitim Bakanlığı], 2016a).

The crucial issue in refugee education is that education can play a supportive role in their adaptation to society but can also have a huge effect on shaping their identities. When Syrian children start education in Turkish schools, they will get classes that focus on Turkish history and Turkish culture. Unfortunately, Turkish education system for elementary, secondary and high schools is not multicultural approach but on Turkish culture. Losing or breaking identity should not be aim of Turkish education system. However, due to lack of multiculturalization in Turkish curriculum, refugee children's identity may break. Moreover, to have a good education life, the integration of family is important.

School and family are two different social institutions and are shaped by different expectations. These different institutions have to meet in a common point about children's education. The problem gets more significant for the first grades because the most basic studying and learning skills form in that year (Şimşek \& Tunaydın, 2002, p. 12-16).

In refugee families, the rate of integration to education system is low. Even some families do not know how to send their children to schools. Language barrier and lack of information play a significant role here. Even if teachers observe some problems in students, they cannot tell their families because neither teachers know families' native languages nor families know teachers' native language. A research made by Mercan Uzun and Bütün (2016) is like a proof of the statements mentioned above. In Samsun, Turkey, teachers who worked with Syrian refugee children in pre-schools stated that they had communication problems both with families and with students. Additionally, teachers observed that some students had hygienic and psychological problems but when they tried to tell these families, they could not have a good communication because of language barrier.

Language barrier is not only limited to preschool children. Communication problem may raise among different age groups. Considering the fact that every child's learning and adapting process is different, learning process takes time. Even though Turkish classes are given in Transitory Education Centers, because all students are Syrian, children do not have any chance to practice speaking Turkish language. In addition, in Turkish society there are some prejudices towards refugees, especially to Syrian refugees. For instance, in Twitter, there are some hashtags about Syrian refugees based on hate speech (\#SyriansGetOut), (\#SyriansBackHome). Due to some distorted news about Syrians, some Turkish people get angry with them. When families have prejudices towards refugees, their children also have prejudices. This situation creates a barrier between Syrian and Turkish children's friendship and Syrian refugees' integration to Turkish society. Considering the fact that friendship ties and attitudes towards each other is significant in childhood in many senses, prejudices of families which transfer to children negatively affect Syrian refugees' integration to Turkish society. Furthermore, economic conditions of refugee families are another important problem for refugee children's education. In Turkey, refugees who have Temporary Protection Document can have access to free education and free health services, but some government schools may require some money for school services in 
registration. Moreover, some cultural trips organized during semester, stationary and clothing expenses are other problems for refugees. Considering the fact that Syrian refugee families have high number of children, it is hard for them to meet all children's need.

Some families find illegal solutions to meet their needs. Child labor is one of the most significant problems. Human Rights Watch' report states that according to A Support to Life Survey, conducted in different cities of Turkey, in İstanbul, at least one child works in 1/3 Syrian households and half of these children are working in textile industry, in Şanlıurfa average age of a child laborer is 14 and in Hatay almost 50 per cent of children refugees are working (2015). Additionally, in Human Rights Watch' report there are some interviews with Syrian refugee children who have been working since they came to Turkey (2015).

Additionally, an important factor that causes refugee children to work at a young age is the lower level of education of their families. According to AFAD, $79.80 \%$ of adult refugees are graduated from middle school and primary school (2017). From this result, it can be easily concluded that not only refugee children but also adult refugees need education. Although younger refugees can learn Turkish in government schools, there is not any attempt for adult refugees on language learning from government. Some NGO's like AID (Alliance of International Doctors) give vocational and language courses for Syrian refugee adults but there is not any government attempt about opening a vocational course for refugee adults. Municipalities have vocational courses for Turkish citizens. For instance, Istanbul Metropolitan Municipalities course centers for gaining professionalism called iSMEK (Istanbul Vocational Training Courses) are free. These courses are almost all around Istanbul. It is a good opportunity to get education in these centers but there is not any concrete step from municipality to create place for refugees in these centers. Also, in Public Education Centre's Turkish for Foreigners classes has opened but refugee families do not have information about it or due to limited budget, they cannot access to these centres.

In spite of these problems, Turkish government made regulation about refugees' employment. According to this regulation, refugees who have Temporary Protection Document and want to be employed can get work permit from Turkish MOI (Ministry of Interior). Refugees can get work permit after 6 months from enrollment to Temporary Protection Document. This regulation gives quota for Turkish businesses that for each workplace the number of workers who have work permit cannot exceed 10 per cent of the total employee number. This regulation also keeps Turkish citizens' employment rights but it may nevertheless affect Turkish employees in a negative way. As reported by World Bank Syrian, the employment of refugees in Turkish labor force will negatively affect informal Turkish labor force regardless of gender or educational level or age (Del Carpio \& Wagner, 2015). To avoid this, new work areas for refugees can be created and job opportunities for Turkish citizens can be expanded.

To conclude, Syrian refugee children's adaptation to Turkish education system and Turkish society is an important step but it is not enough. To sustain their adaptation, families also have to integrate into society. Social, monetary and psychological support for all refugees is crucial. Moreover, having a multicultural curriculum can bring benefits for both refugee and Turkish students. Gaining professionalism and language classes for adults is also important for preventing child labor and increasing refugees' literacy level. In addition, government should share refugee education responsibility with municipalities and NGO's. Refugee education and integration is not one-sided issue and is not only limited to refugees. If all people from different backgrounds and different cultures can meet in at a common point and support each other, problems can be solved easily.

\section{Proposal for A New Multicultural Plan for The Refugee Education in Turkey}

It is significant for refugee children to learn the language of the host country in terms of their education. Preschool, primary school and secondary school education are especially important for language development (Stevens, 2016).

One of the means that will help refugee children absorb the culture of the country they are being sheltered is the education they receive at school (Andriessen \& Phalet, 2002). Subjects that are going to be given are determined within the weekly schedules of schools. Schedules of primary and secondary schools of Turkish National Education Ministry are shaped for the students living in the country. Education at all schools is carried out in accordance with these weekly lesson schedules. Refugee children receive education together with the children of this country in parallel with the lesson schedules prepared for them. Subjects in their present weekly programs are taught in accordance with the curriculum prepared for these lessons by the Ministry of National Education. Present curriculum includes learning goals and aims written for the Turkish citizens residing in Turkey. Curricula is defined as "a mechanism of experiences including all activities related to the teaching of 
a lesson which is planned for the individual to gain inside or outside school" by Demirel $(2005, \mathrm{p}$. 6). When this definition is taken into consideration, education of the refugee children can only be carried out with the syllabus considering the fact that they have been receiving education at same schools and will go on doing so. To achieve this, both education programs and weekly schedules in which courses in the education programs are determined ought to be structured bearing the multi-cultural structure in mind.

As stated before, refugees should be supported for a sustainable life in every aspect. Each individual of the refugee society needs education as well as nutrition, shelter and a hygienic environment. Refugees can use every kind of educational facility in their national education system. However, they are not able to have education according to the same or similar learning targets or attainments when they migrate to a new country as they reside in a new country with a different education system and school structure. Owing to all these facts, a new education model and school environment are needed for the refugee children. Host countries should provide education opportunities for the children regardless of the school type they are attending. Otherwise, refugee children cannot adapt themselves to the culture of the host country. There is a possibility of problems arising from two different scopes, one being in the aspect of the hosting country and the other being from the aspect of the refugees, as they cannot receive official education. Furthermore, it will be more difficult for the refugee children to be part of the community in the future if they do not have education at their budding ages. Therefore, every host country should think, design and practice a unique education system for refugee students.

The curriculum of refugee children should be different from both education systems: from the program of the host country and that of their own country. An effective and sufficient education system, a well-designed weekly schedule and a curriculum, involving multiculturalism and designed for the lessons in this schedule should be evaluated so comprehensively that it should cover every topic that children might need to learn now and in their future lives because existing educational systems and curricula need to be revised according to the changes occurring as a result of movements of migration in the globe. Sustainable changes suitable for the multicultural structure and parallel with the changes occurred after migration should be made so that there can be an egalitarian sharing among all the individuals of the community and in order for democracy to be settled (Salinas, 2006).

It is advised that an effective and proper syllabus should meet the needs of social conditions and provide students who are expected to achieve their goals with necessary knowledge and skills (Aykaç, 2014, p. 42). Curriculum for the refugees having the chance to live in the host country or his own motherland should be designed properly for the two situations mentioned before, considering the multiculturalism possibility. Curricula, which are prepared considering the differences and regard the culture of the host country and the homeland, can raise awareness in students about multi-cultural life. First, curricula including cultural properties of the host country and cultural elements of the refugees' motherlands must be designed. Thus, while refugee students will be able to acquire cultural characteristics of the host country, they will also be able to learn both their own and the global culture (Banks, 2014). Current situation will be able to add awareness of living together with different cultures and achievement of respecting different cultures both to the native and migrated students. By looking at these ideas and with the aim of preventing assimilation, curriculum of the subjects that are in the weekly schedules of refugees should comprise both languages, that of the native language and their own. At the same time, the curricula should include Mathematics, Science, Art and P.E. Other two important courses are Psychological Guidance, Counselling, and Religious Education.

The curricula of these courses should be designed in a way that blends the cultures of both countries and the global culture so that a refugee student will be able to use the things he has learned within this syllabus in different multi-cultural environments. Syllabus of courses in the weekly schedules should be planned, involving the similarities and differences between the new culture and mother culture.

As it will be seen in the attachment, in tables 1 and 2, alternative weekly schedules are proposed for a system in which refugees are involved. Considering refugee students, the first alternative, is a weekly lesson program consisting of Arabic and Culture courses. In table 2, a weekly program is prepared for a curriculum in which Science, Technology, Engineering and Mathematics are predominant, taking STEM teaching model into consideration. Multiculturalism is the foundation of Scientific and Technological Curriculum. 
General Educational Plan for Turkish Primary and Secondary Schools.

\begin{tabular}{|c|c|c|c|c|c|c|c|c|}
\hline \multirow{2}{*}{$\begin{array}{l}\text { Type of School } \\
\text { Courses } \backslash \text { Grades }\end{array}$} & \multicolumn{4}{|c|}{ Primary School } & \multicolumn{4}{|c|}{ Secondary School } \\
\hline & 1. & 2. & 3. & 4. & 5. & 6. & 7. & 8. \\
\hline Arabic * & 0 & 1 & 1 & 1 & 4 & 4 & 4 & 4 \\
\hline Turkish & 7 & 6 & 5 & 5 & 5 & 5 & 5 & 5 \\
\hline Maths & 5 & 5 & 4 & 4 & 4 & 4 & 4 & 4 \\
\hline Science & 3 & 3 & 4 & 4 & 4 & 4 & 4 & 4 \\
\hline Arts & 2 & 2 & 2 & 2 & 2 & 2 & 2 & 2 \\
\hline Music & 2 & 2 & 2 & 2 & 2 & 2 & 2 & 2 \\
\hline Sports & 2 & 2 & 2 & 2 & 2 & 2 & 2 & 2 \\
\hline $\begin{array}{l}\text { Guidance \& P. } \\
\text { Counseling }\end{array}$ & 1 & 1 & 2 & 2 & 2 & 2 & 2 & 2 \\
\hline Religion & 2 & 2 & 2 & 2 & 2 & 2 & 2 & 2 \\
\hline Culture & 3 & 3 & 3 & 3 & 2 & 2 & 2 & 2 \\
\hline Life Skills & 1 & 1 & 2 & 2 & 2 & 2 & 2 & 2 \\
\hline English & 2 & 2 & 2 & 2 & 3 & 4 & 4 & 4 \\
\hline Game & 4 & 4 & 3 & 3 & 1 & 0 & 0 & 0 \\
\hline $\begin{array}{l}\text { Required Lecture } \\
\text { Hours/Week }\end{array}$ & 34 & 34 & 34 & 34 & 35 & 35 & 35 & 35 \\
\hline
\end{tabular}

Table 2

STEM Approach Weekly Course Plan for Syrian Refugee Students.

\begin{tabular}{lcccccccc}
\hline Type of School & \multicolumn{4}{c}{ Primary School } & \multicolumn{5}{c}{ Secondary School } \\
\hline Courses/Grades & $\mathbf{1 .}$ & $\mathbf{2 .}$ & $\mathbf{3 .}$ & $\mathbf{4 .}$ & $\mathbf{5 .}$ & $\mathbf{6 .}$ & $\mathbf{7 .}$ & $\mathbf{8 .}$ \\
Arabic * & 0 & 1 & 1 & 1 & 4 & 4 & 4 & 4 \\
Turkish & 7 & 6 & 5 & 5 & 5 & 5 & 5 & 5 \\
Maths & 5 & 5 & 4 & 4 & 4 & 4 & 4 & 4 \\
Science & 3 & 3 & 4 & 4 & 4 & 4 & 4 & 4 \\
Arts & 2 & 2 & 2 & 2 & 2 & 2 & 2 & 2 \\
Music & 2 & 2 & 2 & 2 & 2 & 2 & 2 & 2 \\
Sports & 2 & 2 & 2 & 2 & 2 & 2 & 2 & 2 \\
Guidance \& P. & 1 & 1 & 2 & 2 & 2 & 2 & 2 & 2 \\
Counseling & 2 & 2 & 2 & 2 & 2 & 2 & 2 & 2 \\
Religion & 3 & 3 & 3 & 3 & 2 & 2 & 2 & 2 \\
Culture & 2 & 2 & 2 & 2 & 3 & 4 & 4 & 4 \\
English & 4 & 4 & 3 & 3 & 1 & 0 & 0 & 0 \\
Game & 33 & 33 & 33 & 33 & 35 & 35 & 35 & 35 \\
Required Lecture & & & & & & & &
\end{tabular}

*In secondary school Arabic has been chosen as elective class. If students select, other elective language classes will be given.

\section{Discussion, Conclusion and Implications}

Refugees are global citizens; though, most countries do not want to integrate them, or have failed to integrate them to the society. Integration concept is basically should not be in the way of assimilation but in general it should be a concept that establishing a social system which meets with all parties demands in society. Considering the fact that education plays a major role in the formation of identity and integration, precautions should be carefully taken in the scope of education and current curricula should be revised. The most significant method of overcoming the issue of refugees is to give them a proper education. Developing a syllabus appropriate for the weekly schedule taking multiculturalism into consideration and integrating STEM education system are appreciated as two ways of raising the sense of belonging and the adaptation of refugees to the society. Holistic and global function of STEM teaching approach cannot be ignored in terms of integration to the society they live in by means of education.

The effect of technology cannot be denied in the process of globalization. Internet use, contributing to the advance of technological development day by day has made the teaching of Mathematics and Science more Engineering and Technology-based. Technology-based teaching approach in Mathematics, Science and Engineering has been widespread, known as STEM. STEM teaching approach, which has been applied in many 
countries as soon as it appeared, aims at students' adoption to interdisciplinary perspective. The fundamental aim of STEM is to bring up students who can use Mathematics and Scientific Studies as technology-productive based and can use this in the social, business and global enterprises (Kırkıç \& Kırkıç, 2018, p.39).

Educational experiences of people from different cultures living in the same environment has been a prevalent situation in the globalizing world. Silicon Valley is a leading place, known worldwide, where technological inventions are made. Most of the scientists working in Silicon Valley come from different countries. $37.80 \%$ of those living in Silicon Valley are immigrants and every 24 minutes a new immigrant comes to the valley (2018, Silicon Valley Population Clock). The practice of STEM based teaching approach in the immigrants' schools will support different cultures to learn together in producing technology as in the example of Silicon Valley. Thus, there will be an opportunity of culturally socializing and the blending of the cultures. In American University of Beirut, STEM education is given to the immigrant students, which helps them adapt to the education and the society they live in (Muller, 2017). In the STEM report prepared by the Turkish Ministry of Education (Turkish Ministry of National Education MEB, 2016b), it has been suggested that STEM teaching approach should be integrated into the preparatory process of curriculum of different subjects. There is not a universal approach to the refugee education as there is in other educational issues; however, there is a need to comprise structures that will enhance cultural adaptation and integration. Although mentalities that will help this adaptation have not been put into practice, though constructed, in scopes such as Medicine, a universal paradigm (a series of values), which will develop abilities at an individual level has not been constructed yet in education.

Yıldıran states that there is a new frame for a universal integration and adaptation. According to Yıldıran, this frame can be neither a Western or Eastern nor Northern or Southern one. This frame can be made up with the culture of every individual and what he has brought from his heritage (Yıldıran, 2006, p. 440-441). Weekly lesson schedules that have been proposed are appropriate for the characteristics of people from different cultures, blended with the cultural features of the culture they come from and the one they live in now, and aiming at raising an awareness of global cultures. It is proposed to the Turkish Ministry of Education that weekly lesson schedules should be evaluated and curricula should be designed in accordance with the situation resulting from the evaluation.

\section{Acknowledgement}

This study was presented by the authors at DAKAM's Interdisciplinary Studies Meeting on 29-30 September 2017.

In this study individuals who came to Turkey with forced migration were called as "refugees". Even they are qualified as Individuals under Temporary Protection, it is the mutual view of the authors to use the term refugee. The writers hope that these people become refugees legally, benefit from more rights and live in better conditions. 


\section{TÜRKÇE SÜRÜM}

\section{Giriş}

Her ne kadar taşınma/yer değiştirme, gelişen teknoloji ve refah seviyesi nedeniyle artmış olsa da farklı bağlamlarda hareket halinde olan çok sayıda insan vardır. Göç hareketleri, tüm dünyada insanların hareketliliğine neden olmuştur. Maalesef, savaş, kıtlık ve bulaşıcı hastalıklar nedeniyle zorunlu göç hareketleri ortaya çıkmıştır. Son on yıla bakıldığında, 2011'de başlayan Suriye savaşı, 5,5 milyon kişinin Suriye'den göç etmesine neden olmuştur (UNHRC, 2016a). Türkiye, Lübnan, Irak, İran, Ürdün, Mısır ve bazı Avrupa ülkeleri Suriyeli mültecilere ev sahipliği yapmaktadır. Türkiye'nin coğrafi konumu, onlara ev sahipliği yapma konusunda Türkiye'yi liderliğe taşımaktadır. Buna ek olarak, Türkiye'nin 1951 yılında imzaladığı Cenevre Sözleşmesi'nde mülteciliği sadece Avrupa'dan gelen bireyler olarak tanıması ve bu coğrafi sınırın hala devam etmesi, zorunlu göç ile Suriye'den gelen bireylerin adlandırılması konusunda tartışmalara yol açmıştır (Birleşmiş Milletler Mülteciler Yüksek Komiserliği Türkiye Temsilciliği, 1961). İlk etapta misafir olarak adlandırılan mülteciler sonrasında Geçici Koruma kapsamında Türkiye'de kayıt altına alınmaya çalışılmıştır. İçişleri Bakanlığı Göç İdaresi'ne göre Türkiye'de 2018 yılı itibariyle Geçici Koruma kapsamında 3.594.232 kişi bulunmaktadır (2018).

Artan sayıda mültecinin, ülkeler üzerinde önemli bir etkisi olduğu gözlemlenmektedir. Ülkeler, artan mülteci nüfusuyla birlikte altyapı, eğitim, sağıık gibi bazı sistemlerini iyileştirmek ve geliştirmek durumunda kalmaktadır. Mültecilerin etkileri sadece kaynak paylaşımıyla sınırlı değildir. Özellikle de çok sayıda genç mültecinin olduğu varsayılırsa demografik sonuçlar da kaçınılmazdır. Bu genç mültecilerin ülkeler üzerindeki etkileri, genç vatandaşların etkileriyle aynıdır. Buna ek olarak, ülkelerin uyguladığı farklı politikaların da mülteciler üzerinde etkisi vardır. Mültecilerin ülkede insani şartlarda yaşaması için gereken eğitim, sağlık ve iş gücüne katılma gibi hakların düzenlenmesi kritik önem taşımaktadır. Özellikle genç mülteci nüfus göz önünde bulundurulduğunda, her gencin olduğu gibi mülteci gençlerin de iyi eğitilmeleri gerekmektedir.

Türkiye'de 18 yaş altında bulunan mültecilerin oranının \%48.00 olduğu dikkate alındığında, uygulanan eğitim politikaları hem mülteci çocukların hem de Türkiye'nin geleceği açısından önemlidir. Türkiye'nin eğitim politikası, mülteci çocukların hayatlarını idame ettirmeleri ve topluma adapte olmaları açısından ince elenip sık dokunması gereken bir konudur. Suriyeli göçmenlerin anadilleri göz önünde bulundurulduğunda görülmektedir ki, göçmen çocukların öncelikle dil engeli bulunmaktadır. Bu problemi çözebilmek için okul öğretim programları yeniden gözden geçirilmelidir. Öğretim programlarında bu düzenlemeler yapılmazsa, sadece Türkiye değil, diğer ev sahibi ülkeler de erken çocuk evliliği, çocuk işçiliği ve göçmenlerin yasadışı çalıştırılması gibi geniş çeşitlilikte sorunla karşı karşıya kalacaktır. Türkiye, çocuk evliliğini azaltmak için senelerdir çok önemli adımlar atmıştır fakat mültecilerin eğitimine odaklanılmaz ise bu problemler yeniden ortaya çıkacaktır. Türkiye, Suriyeli çocuklara ücretsiz eğitim sağlamaktadır ancak göçmenlerin eğitimini üniversiteye kadar zorunlu kılan hukuksal bir madde maalesef bulunmamaktadır. Türkiye vatandaşları için 4+4+4 adı verilen bir sistem ile tüm Türkiye vatandaşları üniversiteye kadar eğitim almak zorundadır. Bu açıdan bakıldığında, Suriyeli öğrenciler, Türkiyeli öğrenciler ile eşit fırsatlara sahip değildir.

Suriyeli göçmenlerin karşılaştıkları çok sayıda zorluk bulunmaktadır. Hem ailelerin hem de çocukların dil engeli, ekonomik şartlar, göçmenlere karşı önyargılar sorunların kaynağı olarak öne çıkmaktadır. Maalesef bu zorluklar nedeniyle Türkiye'deki göçmen çocukların \% 61.00'i okul çağında oldukları halde ilkokula ya da ortaokula kayıt olamamaktadır (UNHCR, 2106b). Suriyeli çocuklar Türkiye tarafından kurulan Geçici Eğitim Merkezleri'nde eğitim almaktadır. Geçici Eğitim Merkezleri hem kamplarda hem de mülteci sayısının yüksek olduğu şehirlerde kurulmuştur. Şehirlerde bulunan bu merkezlerden bazıları devlet okullarının içerisinde bulunmaktadır. Göçmen çocuklar, Türkiye vatandaşı öğrencilerin dersleri sona erdikten sonra günün kalan kısmındaki bir zamanda Geçici Eğitim Merkezleri'nde eğitim almaktadır. Geçici Eğitim Merkezleri'nde Suriye müfredatı takip edilmekte ve öğretmenler de Suriye kökenli öğretmenlerden oluşmaktadır. Ayrıca Türkçe dersleri, Türkiyeli öğretmenlerce verilmektedir. 2017-2018 eğitim-öğretim yılında, Suriyeli öğrencilerin, Türkiyeli öğrencilerle beraber, Türkiye devlet okullarına entegre edilmesi Geçici Eğitim Merkezleri'nin kapatılması planlanmıştır. Günümüzde, Geçici Eğitim Merkezleri'nin birçoğu kapatılmış, Suriyeli mülteci çocukların devlet okullarına geçişi sağlanmıştır. Ancak Türkiye devleti okullarındaki eğitim sistemi entegrasyona dayanmamaktadır. Çok kültürlülüğe dayalı bir ders ya da öğretim programı Türkiye'de devlet okullarında görülmemektedir. Suriyeli ve Türkiyeli çocukların karşılıklı birbirlerinin kültürlerini anlayabilecekleri bir ders bile bulunmamaktadır (MEB, 2018). Çok kültürlülük ve adaptasyon eksikliği nedeniyle dünya genelinde ve Türkiye 
toplumunda göçmenlere yönelik önyargılar baş göstermeye başlamıştır (Tyler, 2006, p. 192). Önyargıları önlemek adına, eğitim sistemi çok kültürlülüğü temel almalı ve öğrencilere evrensel değerler anlatılmalıdır. Ayrıca tüm dünyada göçmenlere karşı nefret söylemleri artmış durumdadır (Bunar, 2007, p. 167).

Türkiye'de de gerek sosyal hayatta gerekse sosyal medyada görülebilen örnekler vardır ("Altın için Komşularını Öldüren Suriyeliler Tutuklandı", 2018). Barış dolu bir toplum için daha bilinçli bir gençlik çok kültürlü bir kimlikle yetiştirilmeli, eğitim sistemleri buna göre tasarlanmalıdır. Bu makalede öncelikle dünya genelinde mültecilerin durumundan bahsedilecek daha sonra da özel olarak Türkiye bazında mültecilerin eğitim hayatının geliştirilmesi için çözüm önerileri sunulacaktır.

\section{Çağdaş Dünyanın “Sorunu”: Mülteciler}

Ormsby'nin de ifade ettiği gibi, 2011 'den bu yana tüm dünyada yer değiştiren insanların sayısı \% 50.00 'den fazla artmıştır (2017). 2011 yılı Suriye'de savaşın başladığı yıl olarak son yıllardaki göçmen sayısının artışı açısından oldukça önemli bir tarihtir. Bu tarihten itibaren bugüne kadar 5,5 milyon kişi göçmen olmaya zorlanarak Suriye dışına çıkmak durumunda kalmıştır (UNHCR, 2016a). Zorunlu göç onları, Afgan ve Güney Sudanlılar gibi, ülkelerini terk etmeye zorlamıştır. "Zorunlu göç, bizim keşfettiğimiz değil bizzat bizim yaptırdığımız bir şey" (Working \& Turton, 2003, p. 3-17) ve uluslararası alanda gerçekleştirilen hamleler zorunlu göçün keşfedilen değil oluşturulan bir olgu olduğunu ortaya koymaktadır.

Siyasi ve ekonomik sorunlar, sadece göçmenlerin hayatını değil, tüm dünyayı etkilemektedir. Yer değiştirme, ev sahibi ülkelerde kaynakların paylaşımı, kültürel değişim gibi birçok soruna yol açabilmektedir. Ayrıca göçmenlerin travmaları, kimlik savaşları ve hayat mücadeleleri üzücü bir biçimde hayatlarına yansımaktadır. Zorunlu göçün en önemli etkilerinden biri, tüm sosyo-ekonomik altyapılardan gelen insanları etkileyebilmesidir. Kişi milyoner, aydın ya da bir iş̧̧i olabilir ama göçten dolayı aynı etkiye aynı anda maruz kalabilir. Birçok insan farkında olmasa da, anne-babalarını savaşta kaybetmeleri, yeni bir ülkede yaşamak zorunda kalmaları ve çocukluk evresinde almaları gereken eğitim, sağlık gibi hizmetlerden yararlanamamaları nedeniyle, göç konusunda en çok çocuklar etkilenmektedir. Örneğin, göç sürecinde ve sonrasında travma ve kronik hastalıklar görülmektedir (Silove et al., 1997). Göç sonrası mültecilerin hayat standartları istikrarlı olarak düşmektedir (Gans, 2009). Ne var ki, bu standartlarda yaşayabilmek için mülteciler, sığındıkları ülkede devletin, yerel yetkililerin, sivil toplum kuruluşlarının ve derneklerin desteğine ihtiyaç duymaktadır. Göçmenlerin hayat standartlarını yükseltmenin bir yolu eğitimdir. Göçmenlere uygun bir eğitim sağlamak, ortak bir kültür oluşturabilmeleri bakımından yaşamlarıı derinden etkileyen bir faktördür. Şahin tarafından yapılan çalışmada, Almanya'da yaşayan Türklerin ortak bir kültür oluşturmaları için eğitimin anlamlı düzeyde etkili olduğu belirlenmiştir (Şahin, 2010).

Yeni bir kültüre adapte olmak mülteciler için çok zordur çünkü genel olarak kendi yapılarından farklı yapısı olan toplumlara göç etmektedirler. Örneğin, en çok göçmen kabul eden ilk 10 ülke incelendiğinde \% 90.00'ının gelişmekte olan ülke olduğu görülmektedir. Gelişmekte olan veya gelişmiş ülkelerde kamplarda kalmak göçmenler için mantıksız olarak algılanmaktadır. Barınmaktan ziyade bu ülkelerde iş imkânları aramak mültecilere daha cazip görünmektedir. UNHCR Türkiye'de göçmenlerin \% 91.00'inin şehirlerde yaşamakta olduğunu belirtmektedir. Bu durum bahsedildiği gibi gelişmekte olan ülkelerde daha iyi iş ve yaşam şartlarına sahip olmak için şehirlere göç edildiğinin bir göstergesidir. Türkiye hükümeti göçmenlere iş izni vermektedir (2017). Bu göçmenlerden bazıları, kendi restoranları veya şirketlerini açan yatırımcılardan oluşmakta, bir kısmı da mavi yakalı olarak çalışmaktadır. Maalesef, yüksek oranda yasadışı çalışma da mevcuttur. Özellikle de büyük şehirlerdeki zor ekonomik koşullardan ve yüksek ev kiralarından dolayı, yüksek fiyatlar ailelerin çocuklarını çalışmaya itmesiyle sonuçlanmaktadır. Ayrıca, iş yeri sahipleri göçmenleri ucuz iş gücü olarak görmekte ve kaçak olarak çalıştırmaktadır (Erdoğan, 2018).

Yasadışı olmasına rağmen, reşit olmayan mülteci çocuklar çalışmaya mecbur kalmaktadır. Amerika Birleşik Devletleri Çalışma Birimi de çocuk işçiliğinin, tekstil, mobilya ve üretim sektörlerinde artmakta olduğunu ve bu çocukların yetişkinlere verilen ücretin yarısını aldıklarını belirtmektedir. Türkiye'de çocuk iş̧̧iliği konusunda oldukça büyük sorunlar bulunmaktadır. Ekonomik sorunlar, hukuksal düzenlemelerdeki yetersizlikler, yoğun olarak yaşanan iç ve dış göçler nedeniyle, Uluslararası Çalışma Teşkilatı verilerine göre, Türkiye'de sayıları yaklaşık olarak 1,600 000 çocuğun iş gücünde yer aldığı belirtilmektedir ("Çocuk İşçiliği", 2018). Avrupa Birliği ülkelerinde ise pek çok ülkede çocuk iş̧iliği yok denecek düzeyde olmasına rağmen, italya'da \%5.00 ve Romanya'da \%1.00 düzeyinde çocuk işçiliği verileri bulunmaktadır (Tat, 2016). Farklı ülkelerin göçmen sayıları, göçmenlerin kökenleri ve ülke içindeki yaşam koşulları çeşitlilik göstermektedir. 
Türkiye'den sonra Pakistan, en çok göçmen ağırlayan ikinci ülke olarak bilinmektedir. Pakistan'daki göçmenlerin çoğu Afganistan'dan gelmiştir. Toplamda, 1.4 milyon göçmen Afganistan'da yaşamaktadır. Afgan göçmenler aynı zamanda Avrupa ülkeleri ve İran'da yaşamaktadır. Aynı zamanda 2016 yılı verilerine göre Irak'ta 953,447 ve Türkiye'de de 118.116 Afgan göçmen yaşamaktadır. Az gelişmiş ülkelerde gelişmekte olan ülkelere göre daha az Afgan mülteci bulunmaktadır (Human Rights Watch, 2017). Afganistan ve Pakistan arasındaki politik meselelerden dolayı, ev sahibi ülke olarak Pakistan, bu mültecilere ülkelerine geri dönmeleri için baskı uygulamaya başlamıştır. UNHCR verileri $2016^{\prime} \mathrm{da}, 1.737 .882$ mültecinin, Afganistan'da insan kaynakları ve iş imkânlarından yoksun olmalarına rağmen Afganistan'a geri döndüklerinden bahsetmektedir (2017b). Afgan mülteciler vakasında çocuk mültecilerin sayısının da çok fazla olduğu göze çarpmaktadır. Afgan mülteci nüfusun yarısından çoğunun çocuk olduğu belirtilmiştir (UNHCR, 2017). Dahası, Pakistan'da yaşayan Afgan mültecilerin \% 74.00'ü 24 yaş altındadır (UNHCR, 2016a). Bu çocuklara eğitim vermek hayati öneme sahiptir çünkü bulundukları coğrafyada göz ardı edilemeyecek ölçüde bir terör problemi bulunmaktadır. Çocukları güvende tutmak ve hayatlarına değer katmak için eğitimin önemi büyüktür.

Lübnan, dünya genelde en fazla mülteci barındıran üçüncü ülkedir. Lübnan'da 1 milyon Suriyeli mülteci bulunmaktadır (UNHCR, 2016a). Lübnan'ın Suriye'ye coğrafi yakınlığı nedeniyle Suriyeli mültecilerle ilgili bazı avantajları bulunmaktadır. Örneğin dil anlamında Lübnan'da da Arapça dili ana dildir ve Suriyeli mülteciler için dil sorunu olmamaktadır. Ayrıca, kültürel farklılıklar, Türkiye'de Suriyeli mültecilerin yaşadığı kültür sorunu ile karşılaştırıldığında daha azdır. Bu durumlara ek olarak, Jesri, tüm Lübnan'a yayılmış olarak resmi kampların bulunmadığını ifade etmektedir (2015). Bu durum eğitime erişimi olumsuz olarak etkilemektedir çünkü hükümet mültecileri bir araya toplayamaz ise onların ihtiyaçlarını karşılamak zorlaşacaktır.

İran dünya genelinde en çok mülteci ağırlayan dördüncü ülkedir. İran sadece Afgan değil, aynı zamanda Suriyeli mültecileri de ağırlamaktadır. UNHCR verilerine göre İran'da 979.435 mülteci bulunmaktadır (2016a). Afgan mültecilere eğitim alanında bakıldı̆̆ında, İran vatandaşları gibi okullara devam edebilmektedir. İran'da mülteci çocuklar ülkelerinin öğretim programına dayalı eğitim almaktadır (UNHCR, 2016b). Bu durum Afgan mülteciler için kritik öneme sahiptir çünkü bu öğretim programı çok kültürlü değildir ve buna ilave olarak mültecilerin kültürüne de uygun değildir.

İran ve Lübnan'a ek olarak, Güney Sudan'daki karışıklıklar nedeniyle, çok sayıda insan da mülteci olmak zorunda kalmıştır. Güney Sudan nüfusunun yaklaşık üçte biri yerlerinden olmuştur. "1,7 milyon Güney Sudanlı ülkeden kaçmış ve yaklaşık 7.5 milyon kişi Güney Sudan sınırları içerisinde acil insani yardım ihtiyacı duymaktadır ve bunların içinde 1.9 milyon kişide ülke içinde göç edenlerden oluşmaktadır" (UNHCR, 2017a). Sudanlılar daha çok komşu ülkelere göç etmektedir. Göç ettikleri ülkeler tıpkı Sudan gibi gelişmemiş ya da gelişmekte olan ülkelerdir. Uluslararası Mülteci Hakları Derneği Uganda'da 1 milyon Güney Sudanlı mülteci olduğunu bildirmektedir (2017). Ev sahipliği yapan ülkelerin ekonomik durumlarından dolayı mülteci eğitiminin fazla başarılı olmadığı belirtilmekle birlikte, UNHCR bu çocukların neredeyse \%65.00'inin eğitime erişememekte olduğunu söylemektedir (2016a).

Tüm bu örneklerden görüldüğü üzere, göç hareketlerinin çocukları çok derinden etkilediği net olarak anlaşılmaktadır. Göçmen çocuklar içinde doğmadıkları kültürlerde eğitim almak zorunda kalmaktadır. Ayrıca, bazı göçmen çocuklar ailelerinden çok daha farklı bir kültüre doğmaktadır. Örneğin AFAD’a göre, Suriye Krizi'nden sonra göç akımları başladığından, Temmuz 2017'ye kadar 224.750 çocuk Türkiye 'de doğmuştur. Zaman geçtikçe bu çocuklar kendi kültürlerinden farklı olan bir toplumda büyüyerek çok kültürlü bireyler haline gelecektir. Muhtemelen çift dilli olacaklar, anadillerini evde öğrenecekler, ev sahibi ülkenin resmi dilini okul da ya da sosyal aktivitelerde öğreneceklerdir. Bu göçmen çocuklar muhtemelen zihinlerinde kimlik ikilemi yaşayacaktır. Ĕger eğitim sistemi göçmenlerin kimliği, dünya çapında değerler ve kültürel kombinasyona göre yeniden düzenlenirse, mülteci çocuklar kurtarılabilir ve topluma yeniden kazandırılabilir.

Kısaca özetlemek gerekirse, dünyadaki mültecilerin yarısından çoğu çocuk grubudur (UNHCR, 2016a). Bu çocukların da normal vatandaş çocuklar gibi eğitim görmeye ihtiyaçları vardır. Çocukların göçmen olarak yaşadıkları ülkeler tarafından onlara karşı sergilenen yaklaşımlar farklı olabilir ancak göç edilen ülke ve göçmelerin kendi ülkelerinin kültürleri arasında eğitim sisteminin de katkısıyla bir entegrasyon sağlanamadığında, göçmen çocukların giderek marjinalleşme olasılığı artacaktır (Şahin, 2010). Çocukları kurtarmak için eğitim önemli bir mekanizmadır ve Dünya Çocukları olarak adlandırdığımız mülteci çocukların eğitimi hem kendi gelecekleri hem de dünyanın geleceği için önem taşımaktadır. Bu çalışmanın bir sonraki bölümünde çok kültürlü sosyalleşme ve mülteci kimliği tartışılacak, daha sonra Türkiye'deki mülteci çocuklar için öğretim programı tavsiyesinde bulunulacaktır. 


\section{Eğitim, Çok Kültürlü Sosyalleşme ve Kimliğin Yeniden Oluşturulması}

Farklı ülkelerin ve farklı kişilerin de farklı kültürleri olur fakat küreselleşme herkesin ortak bir noktada buluşabileceği yeni bir kültür oluşturmuştur. Örneğin küreselleşme sayesinde bir Türkiyeli de kot pantolon giyebilir, bir Japonyalı da. Her iki ülkenin vatandaşı da kendi milliyetlerini belli edecek kıyafetler yerine küreselleşen dünyada farklı kültürden insanların erişebileceği kıyafetleri giymeye başlamıştır. Sadece kıyafet alanında değil eğitim, davranışlar, iş hayatı vb. birçok alanda küreselleşme görülmektedir. İnternet ve sosyal medyanın yaygınlaşması burada önemli bir rol oynamaktadır. Bu kanallar insanlara kültürün sadece ülke sınırlarıyla kısıtlı olmadığını göstermiştir. Bu örneklerden yola çıkarak, farklı geçmişlerden, kültürlerden, ülkelerden, gelen insanların küresel kültür denen yeni bir kültür oluşturduğunu kolaylıkla söylemek mümkündür. Çok kültürlülük ve sosyalleşme, küresel kültürün bir diğer yönü olarak karşımıza çıkmaktadır. Çok kültürlü sosyalleşme süreci, sosyal mekanizmalar yoluyla farklı bir kültürden değerler, davranışlar ve bilinç edinme yoludur. Eğitim, kültürleri birleştiren, yetenekleri keşfeden ve kimlikleri şekillendiren sosyal mekanizmalar içerisinde en etkili olanıdır.

Buna ek olarak eğitim, insan yetenek ve imkânlarının gelişimini geniş ölçüde teşvik eder. Kendi yerini belirleme ve bireyin sahip olduğu potansiyeli araştırma gibi nihai özellikli hedefi ile birey ruhunu ve psikolojisini eğiterek onları güçlü kılmak, eğitim kurumlarının görevi olarak değerlendirilmektedir (Eryılmaz, 2013). Birey kendisini sahip olduğu eğitim yolu ile fark ettirir. Eğitim ailede başlar ve tüm yaşam boyunca devam eder. Aileden alınan eğitim kişisel gelişimin en önemli belirleyici etkenidir. Sahip olunan ebeveynlerden gelen özellikler, yetişme şartları, ait olunan etnik ya da dini topluluk ya da birlikte olunan arkadaş grupları karakter gelişiminin önemli faktörlerdir. Vincent (2003), eğitimin sadece siyasi haklar faaliyeti olmadığını, öte yandan karakterin oluşturulması veya ifade edilmesine giden yol olduğunu belirtmektedir.

Göçmenler bazen kültürel asimilasyon nedeniyle başka bir toplumla iletişim halindeyken kişiliklerini yeniden yapılandırmayı denerler. Bir yandan da bu bireyler kendilerini ait oldukları topluluklarla ayırt ederler. Yerinden olmuş kişiler deşifre olmuş bir kesimdir. İşte bu nedenle, ev sahibi millet içerisinde var olan bir toplanma yeri ihtiyacı hisseder ve kişiliklerini bu şekilde yeniden inşa ederler.

İki topluluk arasındaki çekişmeyi sona erdirmenin toplumun yararına olduğu ilkesini gözeten bir yönetim anlayışı, göç eden kimseleri yerel toplum ile kaynaştırmak için onlara daha çok sosyal rol ve sorumluluk vermelidir (Lordoğlu \& Aslan, 2016). Bu nedenle yerlerinden olmuş bireyler, genel toplumda oynadıkları roller ve aldıkları sorumluluklar itibariyle karakterlerini oluşturabilirler. Yine de, temel olan yerinden olmuş kişilerin tamamen yeni topluma ve kültüre her yönüyle, kendi kültürlerini dışlamadan adapte olmasıdır. Savaştan yeni kaçmış olmaları gerçeğini göz ardı edersek, bireyler kendi anıları ve algılarında kendi toplumlarına sahiplerdi ve algılarındaki bu anılardan, bu kültürden koparılmamaları gerekmektedir.

\section{Göçmenlerin Eğitiminde Çift Dilliliğin Yeri}

Dewey, eğitimin gelecek yaşam için hazırlık değil, bir yaşam süreci olduğunu ve eğitimin insanlara sadece akademik olarak değil aynı zamanda sosyal olarak da değer kattığını belirtmektedir (1897). Öğrenme, değerler, kültürel davranışlar bileşkesi de eğitimin parçasıdır. Günümüzde, eğitimin amacı keskin bir şekilde değişmiştir. Eğitimin değer üretme kısmı, eğitim mekanik bir sistem olarak hizmet etmeye başladığı için azalmıştır. Meyer, eğitimin günümüzde bir süreç gibi değil fakat daha çok bir ürün gibi göründüğünü belirtir (as cited in Bauman, 2003). Öğretim programları, yaratıcılığı geliştirme ve yetenekleri keşfetmeye dayalı değildir. Tüm çocuklar, yetenekleri, bilişleri farklı olmalarına rağmen aynı sınavları olmaktalar.

Bu duruma ek olarak maalesef, insanlar eğitimi işgücü sistemine giriş köprüsü olarak görmektedir. Eğitimin kültürleri, insanları birleştirme rolü insanlar tarafından küçümsenmiş ve odak noktası sadece iş gücü olmuştur. Bu meseleyi çözebilmek için, çok kültürlülük, eğitim sistemi ve öğretim programlarında yer almalıdır. "Çok kültürlü eğitim, tüm sosyal sınıflardan, cinsiyet, etnik, dil ve kültür gruplarından olan öğrencilerin eşit öğrenme fırsatlarına sahip olabilmeleri için bir reform hareketidir" (Banks \& Banks, 2010, p. 481). Çok kültürlü eğitimde dil sınıfları gereklidir. Özellikle de mültecilerin eğitiminde çift dilliliğin önemi çok büyüktür

Yukarıda belirtildiği gibi, tüm dünyada yaklaşık 22.5 milyon mülteci vardır. Ev sahibi ülke vatandaşlarıyla göçmenler arasındaki iletişim oldukça önemlidir. Mültecilerin çift dilliliği aynı zamanda çok kültürlü ilişkileri de desteklemektedir. Çok kültürlülük kişinin kendi kültürünün daha alt düzeyde kalıp başka kültürüne adapte olması, kısaca asimilasyona uğraması olarak değerlendirilmemelidir. Her kültür bir diğerinin dilini, değerlerini, geleneklerini öğrenip kucaklarsa, günlük yaşantısında kullanırsa, çok kültürlü sosyalleşme ortaya çıkar. Sunny Man Chu Lau'nun yürüttüğü araştırmada, Kanada ve Burmalı öğrenciler mektup arkadaşı olurlar. Burmalı öğrencilerin birçoğu mültecidir ve Burmalılar mektuplarının bir bölümünü Burma dilinde yazarlarken 
Kanadalılar, çift dillilik pratiklerini artırmak için İngilizce yazarlar. Bu araştırmanın sonunda öğrencilerin farklı bir dil kullanmaya yönelik bakış açıları daha pozitifleşmiş ve öğrenciler farklı dil öğrenmeye olan korkularından kurtulmuşlardır (Sunny, 2017). Çok kültürlü toplumlarda çift dillilik tek bir etnik ya da kültürel grupla sınırlandırılmamalıdır. Mültecilerin çift dilli oluşu çok kültürlülüğün tek bir kaynağı olamaz. Çünkü ev sahibi ülkede yaşayan insanlar çift dil yeteneklerini geliştirmelidir. Bu tür bir etkileşim her iki taraf için de çok daha faydalı olacaktır.

Çift dilliliğin mülteci eğitimindeki yeri oldukça önemlidir çünkü yeni bir dil öğrenerek mülteci çocuğun kimliği şekillenebilir. Blau ve Duncan'ın belirttiği üzere, “Göçmen gruplar ile diğer etnik azınlık grupların ana akım kültüre katılımları için en önemli araç eğitim olabilir" (Akt. Bankston \& Zhou, 1995). Çok kültürlü eğitim, asimilasyon veya erime değil, adaptasyondur. Böylece, çok kültürlü eğitim ile çift dilliliğin birleşimindeki amaç asimilasyon değil adaptasyon sürecini geliştirmektir. Geçmişte bazı asimilasyon örnekleri farklı kültürlerde görülebilir. ABD kongresinin, 1906 da geçirdiği bir yasa, bir kişi İngilizce konuşamıyorsa vatandaş olma hakkı olmadığını belirtmektedir (Bankston \& Zhou, 1995). Ülkelerdeki bu kısıtlamalar, çok kültürlü çevreyi kısıtlamaktadır. Çift dillilikle ilgili araştırmalar, çift dilli çocukların kendi kültürleriyle bağlarını sürdürdükleri ve diğer kültüre de adapte olabildiklerini göstermektedir ve bu nedenle çift dilliliğin çocukların kültürleri üzerinde olumlu etkileri vardır (Bankston \& Zhou, 1995). Çocukların kendi kültürlerindeki anıları çift dillilik sayesinde canlı kalmaktadır. "Böyle bir dünyada, anı kazanımdır ve ne kadar geriye dayanıyorsa ve ne kadar uzun sürüyorsa o kadar değerlidir" (Bauman, 2013). Ev sahibi ülkeler anının mülteci çocuklar için büyük bir kazanım olduğunun farkına vardıklarında ve eğitim sistemini çok kültürlü değerlere göre şekillendirdiklerinde, mülteci çocuklar daha iyi bir geleceğe sahip olabilecektir.

Sonuç olarak, çok kültürlülük kendisini çift dilli eğitimde göstermektedir. Tüm dünyada 22.5 milyon mülteci olduğu ve bunların yaklaşık 3 milyonunun Türkiye'de yaşadığı değerlendirildiğinde, Türk eğitim sisteminde çok kültürlü değerlere dayalı yeni bir öğretim programına öncelikle ihtiyaç duyulduğu görülecektir. Birbirine karşı olan önyargıları yıkmak için, kültürleri daha iyi anlamak ve toplumda sağlıklı bir kültürel mozaiğe sahip olabilmek için Türkiye'nin eğitim sisteminde reformlara ihtiyaç bulunmaktadır. Sonraki bölümlerde Türkiye' deki göçmenlerin eğitimi analiz edilecek ve Türkiye için bir öğretim programı oluşması yönünde öneride bulunulacaktır.

\section{Türkiye'de Mültecilerin Eğitimi}

Suriye Savaşı Türkiye'deki mültecilerin sayısını önemli ölçüde etkilemiştir. Türkiye'de bulunan mültecilerin yarısından çoğu çocuktur. Suriyeli göçmen çocukların, maalesef, sadece \%39.00'u eğitim hayatlarını Türkiye'de sürdürme şansına sahiptir (UNHCR, 2016b). Çocuklar, ekonomik ve psikolojik problemler, travmatik geçmiş ya da dil engeli nedeniyle okula gidememektedir. Türkiye devleti, Suriyeli göçmenlere geçici oturma izni vermekte ve bu izinle her çocuk devlet okullarına herhangi bir ücret ödemeksizin gidebilme imkânı oluşmaktadır. Türkiye belirli bölgelerde "Geçici Eğitim Merkezi" adı verilen merkezler açılmıştır. Bu eğitim merkezlerinin konumu ve kuruluş misyonundan dolayı, mülteci çocuklar, Türkiye vatandaşı öğrenciler ile birlikte öğrenim görmemektedir. Geçici Eğitim Merkezleri'nde, Suriye müfredatı devam ettirilmekte ve bu öğretim programına ek olarak çocuklar Türkçe de öğrenmektedir. Mülteci çocuklar, Türkiye Devleti okullarına 2017-2018 Güz döneminde öğrenim görmeye başlayabilecektir ve Geçici Eğitim Merkezleri, mülteci öğrencileri Türkiye Devleti okullarına adapte edebilmek için tüm Türkiye'de yavaş yavaş kapatılmaya başlanacaktır (MEB, 2016). Suriye'den beklenmedik oranda göç, sadece Türkiye'yi değil diğer ülkeleri de şaşırtmıştır. Göç sonrası, Türkiye devleti göçmen eğitimi için çözümler bulmaya çalışmıştır. İlk etapta, Suriyelilerin kısa süre sonra ülkelerine döneceği varsayılarak Geçici Eğitim Merkezleri kurulmuştur. Fakat halen, bir kısım göçmen çocuklar yasal olmayan okullara gitmektedir. UNICEF gibi farklı sivil toplum kuruluşları, Geçici Eğitim Merkezlerine maddi anlamda destek vermektedir. UNICEF, Geçici Eğitim Merkezlerindeki öğretmen maaşlarını ve göçmen çocukların aylık taşıma ücretlerini ödemektedir (UNICEF, 2015). MEB, bu geçici eğitim merkezlerinin çoğunu 2017-2018 Güz döneminde kapatmış ve Suriyeli öğrencilerin düzenli olarak devlet okullarına başlamasını sağlamıştır, sadece az sayıda Geçici Eğitim Merkezi eğitime devam etmektedir(MEB, 2016a).

Türkiye'de mülteci eğitimiyle ilgili kritik mesele şudur ki, eğitim mülteci çocukların topluma uyumunda destekleyici bir rol oynamakta fakat aynı zamanda kimliklerin şekillenmesinde de büyük bir etkiye sahip olmaktadır. Suriyeli mülteci çocukların eğitim hayatına katılımını ve devamlılı̆ını negatif etkileyen iki sebep bulunmaktadır. Birincisi, mülteci çocukların yasal olmayan biçimde çeşitli iş alanlarında çalıştırılması ve eğitim hayatından uzak kalmalarıdır. Mülteci çocukların genç yaşta çalışmalarına sebep olan önemli faktörlerden biri ailelerin bu konuda bilinçsiz ve eğitim seviyelerinin düşük olması olabilir. AFAD'a göre Türkiye'de yaşayan Suriyeli yetişkin mültecilerin \%79.80'i ilkokul veya ortaokul mezunudur. İkincisi ise Suriyeli çocuklar devlet 
okullarında eğitim almaya başladıklarında, Türkiye tarihi ve kültürü ile ilgili dersler almak zorunda kalmalarıdır. Maalesef ilk, orta ve lisedeki eğitim sistemi çok kültürlü yaklaşıma değil, Türkiye kültürüne dayalıdır. Kimlik kaybı ya da bozulması Türkiye eğitim sisteminin amacı olmamalıdır ve bunun için haftalık ders çizelgelerinde yer alan derslerin öğretim programı çok kültürlülüğe dayalı olacak şekilde geliştirilmelidir. Buna ek olarak, iyi bir eğitim hayatı için ailenin eğitim hayatına katılımı da önemlidir. Bazı STK'lar, AID (Uluslararası Doktorlar İttifakı) gibi, Suriyeli mülteci yetişkinler için mesleki ve dil kursları vermektedir, ancak mülteci yetişkinler için bir mesleki kurs açma konusunda herhangi bir hükümet girişimi bulunmamaktadır. Belediyelerin Türk vatandaşları için mesleki kursları vardır. Örneğin, İstanbul Büyükşehir Belediyesi'nin iSMEK (İstanbul Mesleki Eğitim Kursları) adlı profesyonelliği kazanma kursları ücretsizdir. Bu kursların hemen hemen hepsi İstanbul civarındadır. Bu merkezlerde eğitim almak iyi bir fırsattır, ancak bu merkezlerde mültecilere yer açmak için belediyeden şu ana kadar somut bir adım atılmamıştır. Ayrıca, Halk Eğitim Merkezi'nin Yabancılar için Türkçe dersi açılmıştır, ancak mülteci aileler bu konuda bilgi sahibi olmadıkları veya sınırlı bütçeye sahip olmaları nedeniyle bu merkezlere erişememektedirler.

Okul ve aile, iki farklı sosyal kurum ve farklı beklentilerle şekillenmektedir. Bu iki farklı kurum, çocukların eğitimi noktasında ortak bir noktada buluşmak zorundadır. Problem, birinci sınıflarda daha önemli hale gelmektedir çünkü en temel çalışma ve öğrenme becerileri ilk yıl atılmaktadır (Şimşek \& Tunaydın, 2002, p. 12-16).

Mülteci ailelerde eğitim sistemine çocuklarının katılımını sağlama oranının düşük olduğu, mülteci çocukların okullaşmaya katılım oranının düşüklüğünden anlaşılabilir. Hatta bazı aileler, çocuklarını nasıl okula göndereceklerini, kayıt edeceklerini bile bilmemektedir. Dil engeli ve bilgi eksikliği burada çok önemli bir rol oynamaktadır. Öğretmenler, öğrencilerde bazı problemler gözlemlese bile, ailelerine bunları anlatamamaktadır, çünkü ne aileler öğretmenin ne de öğretmen ailelerin ana dilini bilmektedir. Mercan Uzun ve Bütün (2016)'ün yaptığı çalışma, yukarıdaki ifadenin ispatı gibidir. Türkiye'nin Samsun ilinde Suriyeli göçmen ailelerin anaokulundaki çocuklarıyla çalışan öğretmenler, hem ailelerle hem de çocuklarıyla iletişim problemleri yaşadıklarını ifade etmişlerdir. Ayrıca, öğretmenler, bazı öğrencilerin sağlık ve psikolojik anlamda problemleri olduğunu da gözlemlemiştir. Ancak bunları ailelerle paylaşmak istediklerinde, dil engeli nedeniyle, iyi bir iletişim sağlayamadıkları araştırmada yer almıştır.

Dil engeli sadece okul öncesi çocuklarla sınırlı değildir. Farklı yaş gruplarında farklı iletişim problemleri ortaya çıkabilir. Her çocuğun öğrenme ve adapte süreci farklı olduğu gerçeğinden hareketle, öğrenme süreci her öğrenci için zaman almaktadır. Geçici Eğitim Merkezlerinde Türkçe dersleri verilmesine rağmen, diğer dersler Arapça olduğu için, çocukların Türkçe konuşma pratiği şansları bulunmamaktadır. Aynı zamanda, Türkiye toplumunda mültecilere, özellikle de Suriyeli olanlara karşı önyargı bulunmaktadır. Örneğin, Twitter'da, nefret söylemine dayalı, Suriyelilerle ilgili hashtagler oluşturulmuştur (\#SuriyelilerDefolsun, \#SuriyelilerEvineDönsün). Suriyelilerle ilgili çarpıtılmış haberlerden dolayı Türkiye vatandaşları, göçmenlere nefret söyleminde ve öfke dolu davranışlarda bulunmuştur. Toplumda yetişkin aile bireylerinin mültecilere ön yargıları olduğunda, çocuklarının da önyargıları olması muhtemeldir. Çocuklukta birbiriyle ilişkilerin ve davranışların birçoğunda önemli olduğu göz önüne alındığında, çocuklara aktarılan ailelerin önyargıları Suriyeli mültecilerin Türk toplumuna entegrasyonunu olumsuz yönde etkilemektedir. Bu durum da Türkiye ve Suriyeli çocukların arkadaşlıklarına ve Suriyeli göçmenlerin Türkiye toplumuna entegrasyonunda engel teşkil etmektedir. Dahası, göçmen ailelerin ekonomik durumları da göçmen çocukların eğitimi açısından da önemli bir problem teşkil etmektedir.

Türkiye'de geçici koruma izni olan göçmenler, ücretsiz eğitim ve ücretsiz sağlık hizmetlerine erişebilmektedir. Ancak bazı devlet okullarının kayıt esnasında okul hizmetleri için para istemekte olduğu gözlemlenmiştir. Ayrıca, okulların organize ettiği kültür turları, kırtasiye masrafları, kıyafet masrafları göçmenler için büyük problem oluşturmaktadır. Suriyeli göçmen ailelerin çocuk sayısının fazla olduğu gerçeğini düşünüldüğünde, ailelerin tüm çocuklarının eğitim ihtiyacını karşılamaları oldukça zordur. Bazı aileler çocuklarının ihtiyaçlarını karşılamak için yasadışı çözümlere başvurmaktadır. Bu yasadışı "çözümlerden" en önemlisi çocuk işçiliğidir. Açık Toplum Vakfı'nın (Open Society Foundation) Yaşam Araştırmasına Desteği raporunda belirttiğine göre ki bu araştırma Türkiye'nin farklı şehirlerinde yürütülmüştür, İstanbul'da Suriyeli hanelerin 1/3'inde en az 1 çocuk çalışmakta ve bu çocukların yarısı tekstil sektöründe çalışmaktadır. Şanlıurfa'da çocuk işçilerin ortalama yaşı 14 olarak gözlemlenmekte ve Hatay'da mülteci çocukların yaklaşık \%50.00'si çalışmaktadır (2016). Mülteci çocukların genç yaşta çalışmalarına sebep olan en önemli faktör de, ailelerin düşük eğitim seviyesi olabilir. 
Sonuç olarak, Suriyeli mülteci çocukların Türkiye eğitim sistemi ve toplumuna adapte olmaları önemli bir adım ancak yeterli değildir. Mülteci çocukların adaptasyonunu sürdürebilmeleri için aileler de topluma adapte olmalıdır. Tüm göçmenler için sosyal, finansal ve psikolojik destek oldukça önemlidir. Dahası, çok kültürlü bir eğitimin hem Türkiyeli hem de mülteci öğrenciler için pek çok faydası vardır. Yetişkinler için meslek edinme ve dil dersleri, çocuk işçiliğini önlemek ve göçmenlerin okur-yazarlık seviyesini artırmak da topluma adaptasyon konusunda çok önemlidir. Ayrıca, devlet, mülteci eğitimi sorumluluğunu belediye ve STK'lar ile paylaşmalıdır. Mülteci eğitimi ve entegrasyonu tek taraflı bir mesele değildir. Kısacası bütünleşme sadece mültecilerle de sınırlı değildir. Farklı geçmişlerden gelen kişiler ve farklı kültürler bir noktada buluşabilirse ve birbirini destekleyebilirse, problemler kolaylıkla çözülecektir.

\section{Türkiye'de Mülteci Eğitimi İçin Yeni Bir Çok Kültürlü Plan Önerisi}

Mülteci çocukların eğitimi açısından ev sahibi ülkenin dilini öğrenmek önemlidir. Dil gelişimi açısından, özellikle okul öncesi, ilkokul ve ortaokul eğitimi önem taşımaktadır (Stevens, 2016). Mülteci çocukların eğitiminde, barındıkları ülkenin kültürünü özümsemelerini sağlayacak araçlardan biri de okulda aldıkları eğitimdir (Andriessen \& Phalet, 2002). Okul eğitiminde verilecek dersler ise haftalık ders çizelgelerinde belirlenmektedir. Milli Eğitim Bakanlığı ilkokul ve ortaokul ders çizelgeleri ülkede yaşayan öğrenciler için oluşturulmuştur. Tüm okullardaki eğitim bu haftalık ders çizelgelerine göre gerçekleştirilmektedir. Mülteci çocuklar, Türkiye'de bulunan okullarda ülkenin çocukları ile birlikte onlar için hazırlanmış ders çizelgeleri ile eğitim almaktadır. Mevcut haftalık ders çizelgelerinde bulunan dersler de Milli Eğitim Bakanlığı tarafından bu dersler için oluşturulmuş öğretim programlarına göre yapılmaktadır. Mevcut öğretim programları Türkiye'de yaşamakta olan Türkiye vatandaşları olan çocuklara göre yazıımış öğrenme amaç ve hedeflerini kapsamaktadır. Demirel (2005, p. 6) tarafından öğretim programı için “öğretim programı, okul ya da okulun dışında bireye kazandırılması planlanan bir dersin öğretimiyle ilgili olan tüm etkinlikleri içine alan yaşantılar düzeneğidir" tanımı yapılmıştır. Bu tanım dikkate alındığında göçmen çocukların eğitimleri, ancak göçmen çocukların da aynı okullarda eğitim aldığı ve alacağı hususunu göz önünde bulunduran öğretim programları ile yapılabilir. Bunun için hem öğretim programları hem de bu öğretim programlarındaki derslerin belirlendiği haftalık ders çizelgeleri, çok kültürlü bir yapıya da dikkat edilecek şekilde yapılandırılmalıdır.

Daha önce de belirtildiği gibi, mülteciler, ev sahibi ülkede sürdürülebilir bir hayat için her yönden desteklenmelidir. Mülteci toplumunun her bir üyesi, gıda, barınma, sağlıklı ortama olduğu kadar eğitime de ihtiyaç duymaktadır. Mülteciler, kendi ülkelerinde yaşarken, kendi milli eğitim sistemlerine göre her türlü eğitsel imkânı kullanabilir. Ancak yeni bir ülkeye göç ettiklerinde aynı veya benzer öğrenme hedefleri ve kazanımlara göre eğitim almamaktadır. Çünkü farklı bir eğitim sistemi ve okul yapısı olan yeni bir ülkede ikamet etmektedirler. Bu gibi nedenlerden dolayı, göçmen çocuklar için yeni bir eğitim yapısı ve okul çevresi gerekmektedir. Ev sahibi ülkeler, çocuk hangi okul türüne devam ediyor olursa olsun, çocuklar için eğitim fırsatı sağlamak zorundadır. Aksi takdirde, mülteci çocuklar, ev sahibi ülkenin kültürüne uyum sağlayamaz. Resmi eğitim alamamalarından dolayı biri ev sahibi ülke açısından diğeri de mülteciler açısından olmak üzere iki farklı alandan sorunlar çıkma olasılığı bulunmaktadır. Üstelik mülteci çocuklar gelişme çağlarında eğitim görmezler ise toplumun bir parçası olmak onlar için gelecekte daha zor olacaktır. Bu nedenle, her ev sahibi ülke, mülteci çocuklar için eşsiz bir eğitim sistemi düşünmeli, tasarlamalı ve uygulamalıdır. Mülteci çocukların öğretim programları, her iki eğitim sisteminden de farklı olmalıdır (ev sahibi ülkenin ve kendi ülkelerinin programından). Etkili ve yeterli bir eğitim sistemi, iyi tasarlanmış haftalık ders çizelgesi ve bu çizelgede bulunan dersler için oluşturulmuş çok kültürlülüğü dikkate alan öğretim programları ile geniş kapsamda değerlendirilmelidir.

Öyle ki çocukların hem şimdiki hem de gelecek yaşamlarında ihtiyaç duyabilecekleri her konuyu içerebilmelidir. Çünkü değişen dünyada ortaya çıkan göç hareketleriyle mevcut eğitim yapılarının ve öğretim programlarının değişimlere göre yenilenmesi gerekmektedir. Demokrasinin yerleşebilmesi ve toplumun tüm bireyleri arasında eşitlikçi bir paylaşımın olması için eğitimde göç ile ortaya çıkan değişimlere paralel, çok kültürlü yapıya uygun, sürdürülebilir değişimler gerçekleştirilmelidir (Salinas, 2006).

Etkili ve iyi bir öğretim programının, hedeflerine ulaşması beklenen öğrencilere gerekli olan bilgiyi, becerileri sağlaması gerektiği ve toplumsal koşullara uygun olması önerilmektedir (Aykaç, 2014, p. 42). Ev sahibi ülkede ya da kendi memleketinde yaşama olasılığı olan mülteciler için öğretim programı çok kültürlülük olasılığına göre ve daha önce bahsedilen iki duruma uygun şekilde planlanmalıdır. Gerek mültecileri barındıran gerekse mültecilerin geldiği ülke kültürünü de dikkate alan, farklılıkları göz önünde bulundurarak hazırlanmış öğretim programların öğrencileri çok kültürlü yaşam konusunda bilinçlendirebilir. Öncelikle ev sahibi ülkenin kültür özellikleri ve ev sahibi ülkeye göç eden göçmenlerin geldikleri ülkelerin kültürel ögelerinin de içinde olduğu 
programlar hazırlanmalıdır. Böylece göçmen öğrenciler ev sahibi ülkenin kültürel özelliklerine sahip olurken, diğer taraftan kendi kültürlerini ve diğer dünya ülkelerinin kültürlerini de öğrenecektir (Banks, 2014).

Gelinen nokta farklı kültürlerin bir arada yaşama farkındalığı ve farklı kültürlere saygı kazanımlarını hem yerli hem de göçmen öğrencilere kazandırabilecektir. Bu fikirlerden yola çıkarak ve asimilasyonu önlemek amacıyla, mültecilerin haftalık ders çizelgelerinde bulunan derslerin öğretim programları, her iki dili de -anadil ve geldikleri yerin dili- kapsamalıdır. Aynı zamanda, Matematik, Fen, Resim ve Beden Eğitimi dersleri de öğretim programı dâhilinde olmalıdır. Diğer iki önemli ders ise, Rehberlik ve Psikolojik Danışmanlık ile Din Eğitimi dersleridir. Bu derslerin öğretim programları göçten önce ve sonra yaşanan ülkelerin kültürleriyle birlikte dünya kültürlerini de içeren tarzda harmanlanarak verilmelidir ki, mülteci bir öğrenci, bu eğitim programında öğrendiklerini farklı çok kültürlü ortamlarda kullanabilmelidir. Haftalık ders çizelgelerinde belirtilen derslerin öğretim programları farklı kültürlerden gelen farklııkları ve benzerlikleri içerecek şekilde oluşturulmalıdır. Ek kısmında görüleceği üzere Tablo 1 ve Tablo 2'de Türkiye'de mültecilerin de eğitime dâhil olduğu bir sistem için alternatif haftalık ders çizelgeleri önerileri görülmektedir. İlk alternatif mülteci öğrencileri de göz önünde bulundurarak Arapça ve kültür derslerinin eklenmesiyle oluşan bir haftalık ders çizelgesidir. Tablo 2'de ise STEM eğitim modeli göz önünde bulundurularak bilim, teknoloji, mühendislik ve matematik eğitimi ağılıklı bir öğretim programı için haftalık ders çizelgesi tasarlanmıştır. Bu iki sistemde de, çok kültürlülük, bilim ve teknoloji öğretim programlarının temelini oluşturmuştur.

\section{Tablo 1.}

Ilk ve Ortaokullar için Haftalık Ders Çizelgesi.

\begin{tabular}{lcccccccc}
\hline Okul Düzeyi & \multicolumn{3}{c}{ ilkokul } & \multicolumn{5}{c}{ Ortaokul } \\
\hline Dersler/Sınıflar & $\mathbf{1 .}$ & $\mathbf{2 .}$ & $\mathbf{3 .}$ & $\mathbf{4 .}$ & $\mathbf{5 .}$ & $\mathbf{6 .}$ & $\mathbf{7 .}$ & $\mathbf{8}$ \\
Arapça * & 0 & 1 & 1 & 1 & 4 & 4 & 4 & 4 \\
Türkçe & 7 & 6 & 5 & 5 & 5 & 5 & 5 & 5 \\
Matematik & 5 & 5 & 4 & 4 & 4 & 4 & 4 & 4 \\
Fen & 3 & 3 & 4 & 4 & 4 & 4 & 4 & 4 \\
Sanat & 2 & 2 & 2 & 2 & 2 & 2 & 2 & 2 \\
Müzik & 2 & 2 & 2 & 2 & 2 & 2 & 2 & 2 \\
Spor & 2 & 2 & 2 & 2 & 2 & 2 & 2 & 2 \\
Rehberlik ve Psikolojik & 1 & 1 & 2 & 2 & 2 & 2 & 2 & 2 \\
Danışmanlık & & & & & & & & \\
Din & 2 & 2 & 2 & 2 & 2 & 2 & 2 & 2 \\
Kültür & 3 & 3 & 3 & 3 & 2 & 2 & 2 & 2 \\
Yaşam Becerileri & 1 & 1 & 2 & 2 & 2 & 2 & 2 & 2 \\
Ingilizce & 2 & 2 & 2 & 2 & 3 & 4 & 4 & 4 \\
Oyun & 4 & 4 & 3 & 3 & 1 & 0 & 0 & 0 \\
Haftalık Tavsiye Edilen & 34 & 34 & 34 & 34 & 35 & 35 & 35 & 35 \\
Ders Saatleri & & & & & & & & \\
\hline
\end{tabular}

Tablo 2.

STEM Yaklaşımlı Haftalık Ders Çizelgesi.

\begin{tabular}{|c|c|c|c|c|c|c|c|c|}
\hline \multirow{2}{*}{$\begin{array}{l}\text { Okul Düzeyi } \\
\text { Dersler/Sınıflar }\end{array}$} & \multicolumn{4}{|c|}{ İlkokul } & \multicolumn{4}{|c|}{ Ortaokul } \\
\hline & 1. & 2. & 3. & 4. & 5. & 6. & 7. & 8. \\
\hline Arapça * & 0 & 1 & 1 & 1 & 4 & 4 & 4 & 4 \\
\hline Türkçe & 7 & 6 & 5 & 5 & 5 & 5 & 5 & 5 \\
\hline STEM Eğitimi & 8 & 8 & 9 & 9 & 10 & 10 & 10 & 10 \\
\hline Sanat & 2 & 2 & 2 & 2 & 2 & 2 & 2 & 2 \\
\hline Müzik & 2 & 2 & 2 & 2 & 2 & 2 & 2 & 2 \\
\hline Spor & 2 & 2 & 2 & 2 & 2 & 2 & 2 & 2 \\
\hline $\begin{array}{l}\text { Rehberlik ve Psikolojik } \\
\text { Danışmanlık }\end{array}$ & 1 & 1 & 2 & 2 & 2 & 2 & 2 & 2 \\
\hline Din & 2 & 2 & 2 & 2 & 2 & 2 & 2 & 2 \\
\hline Kültür & 3 & 3 & 3 & 3 & 2 & 2 & 2 & 2 \\
\hline İngilizce & 2 & 2 & 2 & 2 & 3 & 4 & 4 & 4 \\
\hline Oyun & 4 & 4 & 3 & 3 & 1 & 0 & 0 & 0 \\
\hline $\begin{array}{l}\text { Haftalık Tavsiye Edilen } \\
\text { Ders Saatleri }\end{array}$ & 33 & 33 & 33 & 33 & 35 & 35 & 35 & 35 \\
\hline
\end{tabular}

* Ortaokulda Arapça seçmeli derstir. Eğer öğrenciler isterse diğer seçmeli dil dersleri verilebilir. 


\section{Tartışma, Sonuç ve Öneriler}

Mülteciler dünya vatandaşlarıdır ancak çoğu ülke onları entegre etmek istememektedir ya da topluma entegre etmek konusunda başarısız olmuştur. Eğitimin, gerek kimlik oluşumunda gerekse entegrasyonda önemli rolü olduğunu düşünülürse, özellikle eğitim alanında dikkatli önlemler alınmalı ve öğretim programları revize edilmelidir. Entegrasyon kavramı temel olarak asimilasyon yolunda olmamalı, ancak genel olarak toplumdaki tüm tarafların talepleri ile bir araya gelen bir sosyal sistem kurması bir kavram olmalıdır. Türkiye'de mülteciler "sorununun" üstesinden gelmenin en önemli yolu onlara uygun bir eğitim vermektir. Çok kültürlülüğün de dikkate alındığı bir haftalık ders çizelgesine uygun öğretim programı geliştirmek ve STEM eğitim sistemini entegre etmek, aitlik duygusunu ve mültecilerin topluma uyumunu artıracak iki yol olarak değerlendirilmektedir. STEM öğretim yaklaşımının bütüncül ve küresel olan işlevi, mültecilerin eğitim sistemi ile yaşadıkları topluma entegrasyonunda dikkate alınması gereken bir husustur.

Küreselleşen dünyanın bu sürecinde teknolojinin etkisi yadsınamaz. İnternet kullanımının teknoloji gelişimini her geçen gün arttırması, matematik, fen öğretimlerini daha mühendislik ve teknoloji odaklı hale getirmiştir. Matematik, fen ve mühendislik alanlarındaki teknoloji odaklı öğretim yaklaşımı STEM adıyla yaygınlaşmaya başlamıştır. Ortaya çıkışı ile dünya genelinde pek çok ülkede uygulanan STEM öğretim yaklaşımı, öğrencileri disiplinler arası bakış açııını benimsemelerini hedeflemektedir. Öğrencilerin bilimi, matematik ve mühendislik alanlarını teknoloji üretme odaklı kullanarak okul, toplum, iş ve küresel girişimlerde hayata geçirebilen öğrenciler olarak yetiştirilmesi, STEM yaklaşımın temel amacıdır (Kırkıç \& Kırkıç, 2018, p. 39).

Farklı kültürlerden gelen kişilerin aynı ortamlarda yaşayacakları öğretim deneyimleri, küreselleşen dünyada her geçen yıl daha da yaygınlaşan bir durumdur. Silikon Vadisi, teknolojik buluşların yapıldığı dünya çapında bilinen öncü bir yerdir. Silikon vadisinde çalışan bilim insanlarının büyük bir kısmı farkı ülkelerden gelmiştir. Silikon vadisinde yaşayanları \%37.80'i göçmendir ve vadiye her yirmi dört dakikada bir göçmen gelmektedir (Silicon Valley, 2018). STEM temelli öğretim yaklaşımının mültecilerin öğrenim göreceği okullarda uygulanması, Silikon vadisi örneğinde olduğu gibi farklı kültürlerin teknoloji üretme konusunda birlikte öğrenmelerini destekleyecektir. Böylelikle kültürel olarak kaynaşmalarına, kültürlerin harmanlanmasına da olanak sağlanmış olacaktır. Beyrut Amerikan Üniversitesi'nde "Mülteci Çocuklar İçin STEM" eğitimleri yapılmakta ve mülteci çocukların eğitimleri gerçekleştirilirken yaşadıkları toplumla kaynaşmalarını sağlanmaktadır (Muller, 2017). Türkiye Milli Eğitim Bakanlığı tarafından hazırlanan STEM raporunda, STEM öğretim yaklaşımının çeşitli derslerin öğretim programlarının hazırlık süreçlerine katılması önerilmiştir (Milli Eğitim Bakanlığı [MEB], 2016b).

Mülteci çocukların eğitimi konusunda, diğer eğitim konularında olduğu gibi evrensel bir yaklaşım bulunmamakla beraber, kültürel olarak kaynaşmayı ve bütünleşmeyi sağlayacak yapıların oluşturulmasına intiyaç duyulmaktadır. Bu kaynaşmayı sağlayacak düşünce yapıları, tıp gibi alanlarda olduğu gibi, tamamen yaşama yansıtılamamış olsa da, oluşturulmuş olmasına rağmen eğitim alanında bireysel düzeyde yetenekleri geliştirecek evrensel bir paradigma (değerler dizisi) henüz hayata yansıtılabilmiş değildir. Yıldıran, evrensel bütünleşme ve kaynaşma için yeni bir çerçeveye ihtiyaç duyulduğunu belirtmektedir. Yıldıran'a göre bu çerçeve ne batı, ne doğu, ne kuzey, ne de güney çerçevesi olamaz. Bu çerçeve farklı kültürlerdeki her bireyin kültürüne ve geçmiş mirasından getirdikleri ile oluşturulabilir (Yıldıran, 2006, p. 440-441). Önerimiz olan haftalık ders çizelgeleri de farklı kültürlerden gelen kişilerin özelliklerine uygun, geldikleri ve yaşamaya devam ettikleri toplumun kültürel özellikleri ile harmanlanmış, dünya kültürleri farkındalığı oluşturmayı hedefleyen bir amaç taşımaktadır. Haftalık ders çizelgesi önerilerinin değerlendirilmesi ve değerlendirme sonuçlarına göre ortaya çıkan duruma uygun ders öğretim programlarının hazırlanması Türkiye Milli Eğitim Bakanlı̆̆ı'na önerilmektedir.

\section{Bilgilendirme}

Bu çalışma 29-30 Eylül 2017 tarihinde DAKAM's Interdisciplinary Studies Meeting'de sözlü bildiri olarak sunulmuştur.

Bu çalışmada Suriye'den Türkiye'ye zorunlu göç ile gelen bireyler mülteci olarak adlandırılmıştır. Türkiye tarafından Geçici Koruma Altında olan bireyler olarak nitelendirilseler de bu makalede mülteci olarak adlandırılmaları yazarların ortak görüşüdür. Yazarlar, tüm bu insanların yasal olarak mülteci olmalarını, daha fazla haktan faydalanmalarını ve yaşamlarını daha iyi koşullarda sürdürmelerini umut etmektedir. 


\section{References}

AFAD (2017). Suriyeli sığınmacılara yapılan yardımlar. Retrieved from: https://www.afad.gov.tr/upload/Node/2373/files/Suriyeli_Siginmacilara_Yapilan_Yardimlar+7.pdf $\quad[10$ Ağustos 2017].

Aile ve Sosyal Politikalar Bakanlığı, Aile ve Toplum Hizmetleri Genel Müdürlüğü. (2015). Türkiye'de evlilik tercihleri. Retrieved from: <http://ailetoplum.aile.gov.tr/data/54292ce0369dc32358ee2a46/t\%C3\%BCrkiyede\%20evlilik\%20tercihleri \%20ara\%C5\%9Ft\%C4\%B1rmas\%C4\%B1\%202015.pdf> [07.09.2017].

Altın için Komşularını Öldüren Suriyeliler Tutuklandı. (2018). Retrieved from: http://www.iha.com.tr/bursahaberleri/altin-icin-komsularini-olduren-suriyeliler-tutuklandi-bursa-2078911/),[13.11.2018].

Andriessen, I. \& Phalet, K. (2002). Acculturation and school success: A study among minority youth in the Netherlands. Intercultural Education, 13(1), 21-36. Doi: 10.1080/14675980120112913

Aykaç, N. (2014). Öğretim ilke ve yöntemleri. Ankara: Pegem Yayıncılık.

Banks, J. A. \& McGee Banks, C. A. (2010). Multicultural education: Issues and perspectives. John Wiley \& Sons.

Banks, J. A. (2014). Diversity, Group Identity, and Citizenship Education in a Global Age. The Journal of Education, 194,3, 1-12. Retrieved from: https://www.jstor.org/stable/43823659?seq=1\#metadata_info_tab_contents

Bankston, C., \& Zhou, M. (1995). Effects of minority-language literacy on the academic achievement of Vietnamese Youths in New Orleans. Sociology of Education, 68(1), 1-17.

Bauman, Z. (2003). Educational challenges of the liquid-modern era. Diogenes, 50(1), 15-26.

Birleşmiş Milletler Mülteciler Yüksek Komiserliği Türkiye Temsilciliği (1961). Mültecilerin hukuki statüsüne ilişkin sözleşme. $\quad$ Retrieved from: http://www.goc.gov.tr/files/files/multec\%C4\%B1ler\%C4\%B1nhukuk\%C4\%B1statusune\%C4\%B1l\%C4\%B1sk \%C4\%B1nsozlesme.pdf

Bunar, N. (2007). Hate crimes against immigrants in Sweden and community responses. American Behavioral Scientist, 51(2), 166-181. http://dx.doi.org/10.1177/0002764207306049

Demirel, Ö. (2005). Kuramdan uygulamaya eğitimde program geliştirme. Ankara: Pegem Akademi Yayınları.

Dewey, J. \& Dewey, E. (2008). Schools of tomorrow. New York: Dover Publications.

Erdoğan, M. M. (2018). Türkiye’deki Suriyeliler - Toplumsal kabul ve uyum. İstanbul Bilgi Üniversitesi Yayınları.

Eryılmaz, A. (2013). Using of positive psychology on psychological counseling and guidance context on character strength and preventive services. The Journal of Happiness \& Well-Being, 1(1), 1-20.

Eurostate News Release. (2016). Acquisition of citizenship in the EU. EU Member States granted citizenship to almost Moroccans continue to be the main recipients. Retrieved from: <http://ec.europa.eu/eurostat/documents/2995521/6897702/3-01072015-AP-EN.pdf/2bbb6946-d2ba48e9-be57-4c226cd8f6c9> [12.07.2018].

Gans, H.J (2009) First generation decline: downward mobility among refugees and immigrants. Ethnic and Racial Studies, 32(9), 1658-1670, Doi: 10.1080/01419870903204625.

Hamers, J. F., \& Blanc, M. (2000). Bilinguality and bilingualism. Cambridge: Cambridge University Press.

Human Rights Watch. (2017). Pakistan Coersion, UN Complicity: The Mass Forced Return of Afghan Refugees.

International Refugee Rights Association. (2017). Uganda'daki Güney Sudanlı mülteciler 1 milyonu aştı. Retrieved from: < http://umhd.org.tr/?s=219>. [06.09.2017]

İçişleri Bakanlığı Göç İdaresi. (2018). Geçici koruma. Retrieved from: http://www.goc.gov.tr/icerik6/gecicikoruma_363_378_4713_icerik.[13.11.2018].

Jesri, H. (2015). Educating Syrian refugee children in Lebanon: the challenge \& the opportunity. Retrieved from: <http://www.bold-mag.com/site/article.php?issueld=117\&catld=42\&articleld=725\#.WXm0M1V97IV> [22.07.2017].

Kırkıç, K. A. \& Kırkıç, A. P. (2018). Teknoloji toplumu, eğitim programları ve STEM. In: Merhaba STEM Yenilikçi bir öğretim yaklaşımı, (Eds. Aydın., E \& Kırkıç, K.A.). Konya: Eğitim Yayınevi. 
Lordoğlu, K., \& Aslan, M. (2016). En fazla Suriyeli göçmen alan beş kentin emek piyasalarında değişimi: 20112014. Çalışma ve Toplum, 49(2).

Mercan Uzun, E., \& Bütün, E. (2016). Okul öncesi eğitim kurumlarindaki Suriyeli siğinmaci çocuklarin karşilaştiklari sorunlar hakkinda öğretmen görüşleri. Uluslararası Erken Çocukluk Eğitimi Çalışmaları Dergisi, 1(1), 72-83. Retrieved from http://dergipark.gov.tr/ijeces/issue/22947/175325

Milli Eğitim Bakanlı̆̆ı (Turkish Ministry of Education [MEB]). (2016a). Suriyeli Öğrenciler Türk Eğitim Sistemine Entegre Edilecek. Retrieved from: <http://www.meb.gov.tr/suriyeli-ogrenciler-turk-egitim-sistemineentegre-edilecek/haber/11815/tr >. [09.07.2017].

Milli Eğitim Bakanlığı (Turkish Ministry of Education [MEB]). (2016b). STEM eğitim raporu. Retrieved from: http:/yegitek.meb.gov.tr/STEM_Eğitim_Raporu.pdf. [27.02.2018]

Milli Eğitim Bakanlığı (Turkish Ministry of Education [MEB]). (2018). Ilköğretim kurumlarindaki (ilkokul ve Ortaokul) haftalik ders çizelgesi. Retrieved from: http://ttkb.meb.gov.tr/www/haftalik-derscizelgeleri/kategori/7 [13.11.2018].

Milligan, M. J. (2003). Displacement and identity discontinuity: The role of nostalgia in establishing new identity categories. Symbolic Interaction, 26(3), 381-403.

Muller, J. (2017). STEM for Refugees launches innovative response to educating refugee youth. Retrieved from: http://website.aub.edu.lb/news/2017/Pages/stem-refugees.aspx [27.02.2018].

National Intelligence Council. (2017). Global trends, (March), 1-14. Retrieved from: <http://www.gov.mb.ca/agriculture/statistics/food/global_sustainability_trends_en.pdf\%5Cnpapers2://pu blication/uuid/90B693DC-9A38-40A2-B81E-1916F6471E1D> [12.07.2017].

Okyay, A. S. (2017). Labour market integration of Syrian refugees in Germany and Turkey: Challenges and prospects. Global Turkey in Europe Working Paper 18.

Open Society Foundation. (2016). On the brink of a lost generation. Retrieved from: http://aciktoplumvakfi.org.tr/pdf/On_the_Brink_of_a\%20Lost_Generation.pdf [12.08.2017]

Ormsby, E. A. (2017). The Refugee Crisis as Civil Liberty Crisis. Columbia Law Review, 1191-1231.

Salinas, C. (2006). Educating Late Arrival High School Immigrant Students: A Call for a More Democratic Curriculum. Multicultural Perspectives, 8(1), 20-27. Doi: 10.1207/s15327892mcp0801_4.

Silicon Valley Population Clock. (2018). https://siliconvalleyindicators.org/snapshot/. [29.09.2018]

Silicon Valley. (2018). https://siliconvalleyindicators.org/snapshot/ (29.09.2018).

Silove, D., Sinnerbrink, I., Field, A., Manicavasagar, V., \& Steel, Z. (1997). Anxiety, depression and PTSD in asylum-seekers: assocations with pre-migration trauma and post-migration stressors. The British Journal of Psychiatry, 170(4), 351-357.

Sonn, C. C., Ivey, G., Baker, A., \& Meyer, K. (2017). Post-Apartheid South African immigrants in Australia: Negotiating displacement, identity, and belonging. Qualitative Psychology, 4(1), 41-54.

Sunny, M.C. L. (2017). Intercultural education through a bilingual children's rights project: reflections on its possibilities and challenges with young learners. Intercultural Education, 26(6), 469-482.

Şimşek, H. \& Tunaydın, D. (2002). Illköğretimde veli katilimi: Öğretmen-veli-psikolojik danışman üçgeni. ilköğretim-Online, 1(1), 12-16.

Turton, D. (2003). Conceptualising forced migration. RSC Working Papers Series.

Tyler, I. (2006). "Welcome to Britain" The cultural politics of asylum. European Journal of Cultural Studies, 9(2), $185-202$

Uluslararası Çalışma Örgütü. (2018). Çocuk İşçiliği. Retrieved from: https://www.ilo.org/ankara/areas-ofwork/child-labour/lang--tr/index.htm. [21.08.2017].

United Nations High Commissioner for Refugees Representation in Turkey. (2018). Agreement on the legal status of refugees. Retrieved from: http://www.goc.gov.tr/files/files/multec\%C4\%B1ler\%C4\%B1nhukuk\%C4\%B1statusune\%C4\%B1|\%C4\%B1sk \%C4\%B1nsozlesme.pdf [21.08.2017]. 
Kamil Arif Kırkıç, Ayşe Perihan Kırkıç, Şeyma Berberoğlu - Uluslararası Eğitim Programları Dergisi, 8(2), 233-254

UNHCR (1990). Convention on the Rights of the Child. Retrieved from https://www.ohchr.org/en/professionalinterest/pages/crc.aspx [21.08.2017].

UNHCR (2016a). Global Trends, Forced Displacement in 2016. Retrieved from: https://www.unhcr.org/5943e8a34.pdf [21.08.2017].

UNHCR. (2016b). Missing Out: Refugee Education in Crisis. Retrieved from: https://www.unhcr.org/57d9d01d0 [21.08.2017].

UNHCR. (2017a). South Sudan Situation - Uganda, (MAY). Retrieved from: $<$ http://data.unhcr.org/SouthSudan/country.php?id=229> [21.08.2017].

UNHCR. (2017b). Turkey refugee crisis. ECHO Factsheet, (July). Retrieved from: http://ec.europa.eu/echo/files/aid/countries/factsheets/thematic/Forced_Displacement_en.pdf [25.07.2017]

UNICEF (2015). Suriyeli Öğretmenler UNICEF Aracılı̆̆ıla Aldıkları Teşvikten Ötürü Memnun. Retrieved from: http://www.unicef.org.tr/basinmerkezidetay.aspx?id=22566 [06.09.2017].

Vincent, C. (2003). Social justice, education and identity. Routledge.

Wagner M. \& Del Carpio X. (2015) The Impact of Syrians Refugees on the Turkish Labor Market, World Bank Group, Social Protection and Labor Global Practice. 